\title{
WestVirginiaUniversity
}

THE RESEARCH REPOSITORY @ WVU

Graduate Theses, Dissertations, and Problem Reports

2014

\section{Polish Immigration to the U.S. since 1980 as a Political Question}

\author{
Pawel Majcher \\ West Virginia University
}

Follow this and additional works at: https://researchrepository.wvu.edu/etd

\section{Recommended Citation}

Majcher, Pawel, "Polish Immigration to the U.S. since 1980 as a Political Question" (2014). Graduate Theses, Dissertations, and Problem Reports. 341.

https://researchrepository.wvu.edu/etd/341

This Thesis is protected by copyright and/or related rights. It has been brought to you by the The Research Repository @ WVU with permission from the rights-holder(s). You are free to use this Thesis in any way that is permitted by the copyright and related rights legislation that applies to your use. For other uses you must obtain permission from the rights-holder(s) directly, unless additional rights are indicated by a Creative Commons license in the record and/ or on the work itself. This Thesis has been accepted for inclusion in WVU Graduate Theses, Dissertations, and Problem Reports collection by an authorized administrator of The Research Repository @ WVU. For more information, please contact researchrepository@mail.wvu.edu. 
Polish Immigration to the U.S. since 1980 as a Political Question

\author{
Pawel Majcher
}

Thesis submitted

to the Eberly College of Arts and Sciences

at West Virginia University

in partial fulfillment of the requirements for the degree of

Master of Arts in

History

Robert E. Blobaum, Ph.D., Chair

Joshua Arthurs, Ph.D.

James Siekmeier, Ph.D.

Department of History

Morgantown, West Virginia

2014

Keywords: Polish emigration, U.S. immigration policy, U.S.-Polish relations, contemporary history 


\section{ABSTRACT \\ Polish Immigration to the U.S. since 1980 as a Political Question \\ Pawel Majcher}

The purpose of this thesis is to present the U.S. policy towards Polish immigration to the U.S. during the two decades of 1980's and 1990's and assess its impact and consequences on Polish immigrants. Using primary and secondary sources, this work primarily aims to answer the question whether and how U.S. immigration policy in 1980's and 1990's affected Polish immigration to the U.S.. The first chapter outlines the nature of American immigration policy and demonstrates the evolution of the U.S. immigration and refugee policy. I answer the question of how the U.S. immigration and refugee system evolved in the past and on what principals it was based. In the second section I analyze the impact of the main U.S. immigration and refugee laws on Polish immigration in the last decade of communism in Poland. In the third chapter, I analyze how the main U.S. immigration policies impacted Polish immigration to the U.S. after collapse of communism in Poland. I demonstrate that while Polish immigrants were no longer eligible to apply for refugee status, the number immigrating to the U.S. did not decrease. Poles immigrated to the U.S. on the basis of different laws. This study was conducted both at West Virginia University (USA) and Collegium Civitas (Poland). 


\section{TABLE OF CONTENTS}

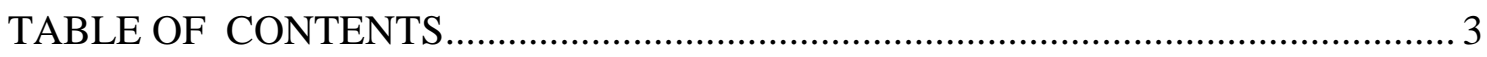

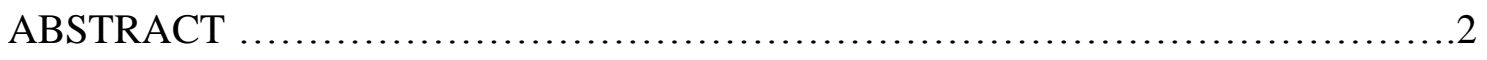

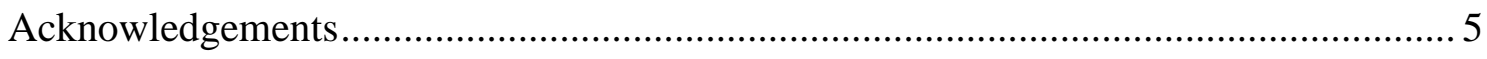

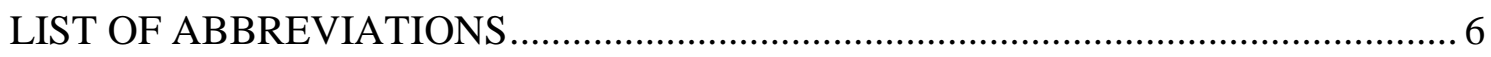

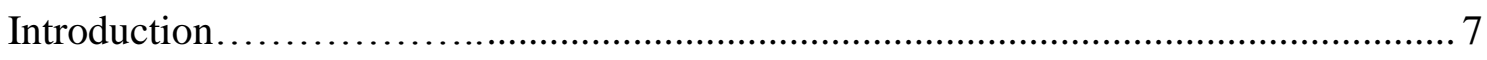

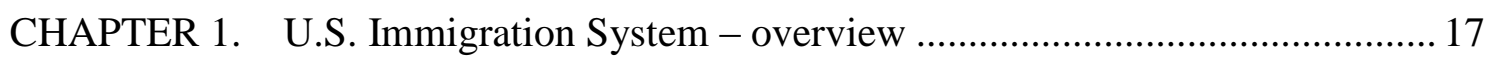

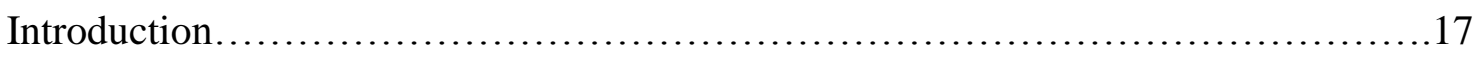

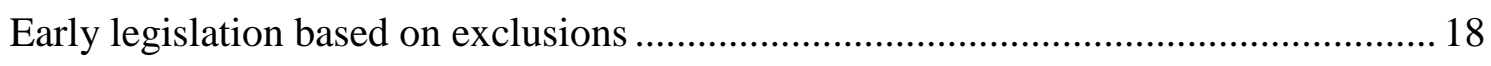

First Formulation of a Comprehensive Immigration Policy- International limits .......... 19

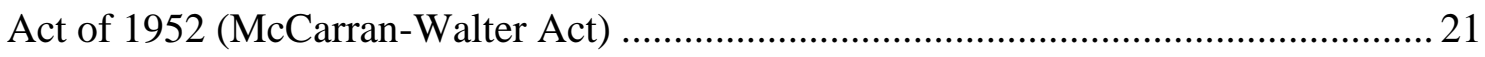

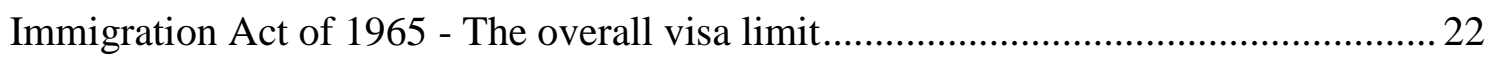

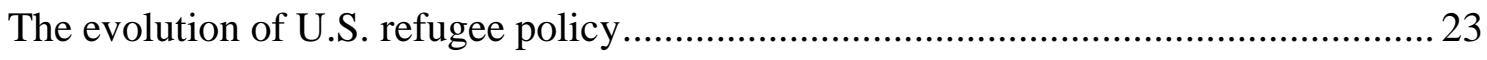

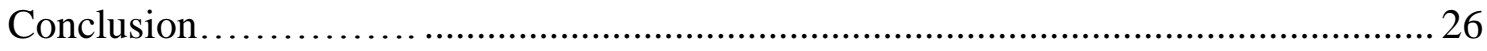

CHAPTER 2.Polish Political Immigration in the 1980's ......................................... 27

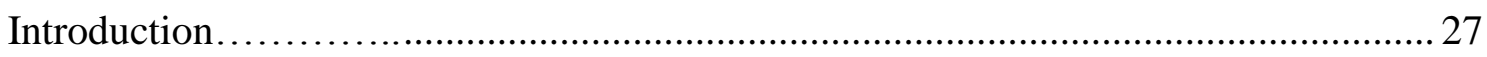

Intensification of migration determinants after martial law ..................................... 27

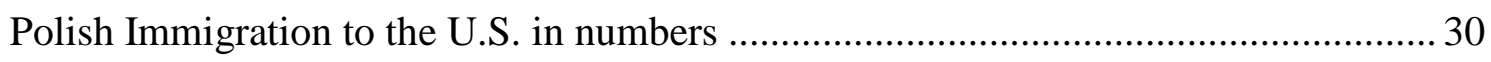

American reaction toward the imposition of Martial Law in Poland and the impact of

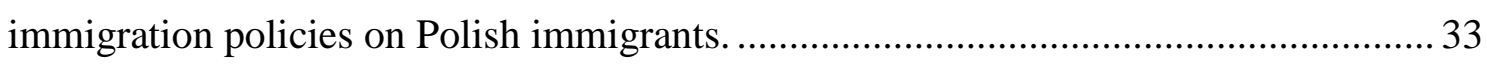

Impact of the Refugee Act of 1980 on Polish newcomers .......................................... 34

EVD (Extended Voluntary Departure) and Polish Immigrants .................................. 37

Wakacjusze and the Immigration Reform and Control Act ( IRCA ) of 1986 .............. 40 
Difficulties of Polish immigrants

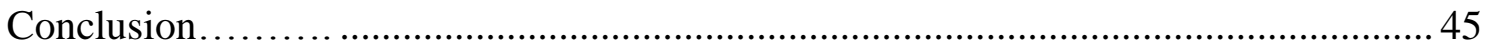

CHAPTER 3.Polish Immigration to the U.S. since 1990 …........................................ 47

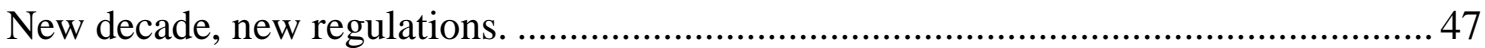

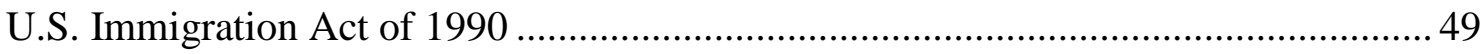

Act of 1990, DV Visa Lottery and the Polish case ........................................................ 51

VWP - the Visa Waiver Program and the Polish case ................................................... 55

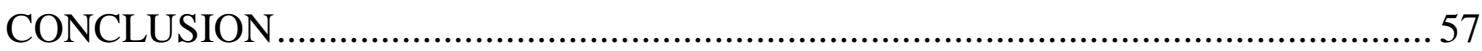

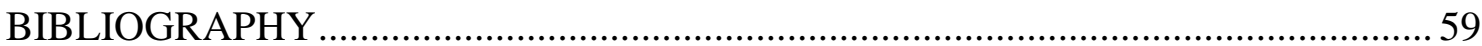




\section{ACKNOWLEDGEMENTS}

I would like to express my sincere gratitude to my advisors Prof. Robert Blobaum and Prof. Dariusz Stola for their continuous support during the Atlantis Scholarship Exchange and thesis research, for their patience, motivation, enthusiasm, and immense knowledge. Their guidance helped me throughout the research and writing of this thesis. I could not have imagined having better advisors and mentors for my Masters study. Besides my advisors, I would like to thank the rest of my thesis committee: Prof. Joshua Arthurs, and Prof. James Siekmeier, for their encouragement, insightful comments, and hard questions. Last but not the least, I would like to thank my family which has been a constant source of support - emotional, moral and of course financial - and this thesis would certainly not have written without it. They supported me in spirit throughout my life, whether in Poland or abroad. 


\section{LIST OF ABBREVIATIONS}

CBP- Customs and Border Protection

ECE-Economic Commission for Europe

EVD-Extended Voluntary Departure

ICE- Immigration and Customs Enforcement

INS- Immigration and Naturalization Service

IRS- Internal Revenue Service

IRCA- Immigration Reform and Control Act

LPR- Legal Permanent Resident

PAIRC- Polish American Immigration and Relief Committee

USCIS- United States Citizenship and Immigration Services

U.N.-United Nations

VWP- Visa Waiver Program 


\section{INTRODUCTION}

Give me your tired, your poor,

your huddled masses, yearning to breathe free;

The record refuse of your teeming shore,

Send these, the homeless, tempest-tost to me,

I lift my lamp beside the golden door ${ }^{1}$

(Emma Lazarus, 1883)

The U.S. is a country created by the successive immigration waves - a mix of many nationalities and cultures. Almost all U.S. residents are immigrants or descendents of different nations, who celebrate their immigrant heritage. For many it is a country of residence more often by choice or forced migration, than by birth. For generations, its myth of freedom fascinated many newcomers who arrived with hopes of rapid social and economic mobility. Nevertheless this process did not always correspond with social class upgrade for many immigrants. ${ }^{2}$ The twentieth-century immigration flows to the U.S. could also be perceived as one of the most characteristic consequences of turmoil when the two great totalitarian regimes in Europe pushed many to migrate. In many historical cases, emigration became almost the only form of selfdefense not only against social degradation and cultural confusion, but also the loss of liberty or even life. Accordingly, Poles throughout their history, immersed in internal political and economic problems, left homes in hopes of a better life or survival in general. Immigration was a form of not accepting the reality of economic and political conditions in their home country. ${ }^{3}$

Nevertheless, apart from those trends and shifts of Polish immigration to the U.S., migration tendencies also were affected by external factors such as U.S.

\footnotetext{
${ }^{1}$ Emma Lazarus and Gregory Eiselein, Selected Poems and Other Writings (Peterborough, Ont.; Orchard Park, NY: Broadview Press, 2002), 233.

2 Mary Patrice Erdmans, Opposite Poles: Immigrants and Ethnics in Polish Chicago, 1976-1990 (University Park, PA: Penn State University Press, 1998), 73.

3 Krystyna Slany, "Emigracje z Polski w latach osiemdziesiątych do głównych krajów imigracji zamorskiej i kontynentalne: Aspekty demograficzno-społeczne”, Przegląd Polonijny, (1991:4):33.
} 
immigration policy that has been constantly evolving throughout the twentieth century. While the U.S. always played a tremendous role in the immigration market and the Statue of Liberty symbolized the willingness of the U.S. to open its gates to immigrants, the intense inflow of immigrants and internal social attitudes made U.S. immigration policies more restrictive, preventive and exclusive.

The purpose of this thesis is to present American policy towards Polish immigration to the U.S. during the 1980's and 1990's and assess its impact and consequences on Polish immigrants. Using primary and secondary sources, this work will primarily aim to answer the questions: Did immigration policy changes in the 1980's and 1990's influence Polish immigration? If so, then did those immigration acts encourage Poles to immigrate or make Polish immigration to America more difficult and complicated? Moreover, it will be crucial to see how Poland was inscribed into the worlds U.S. immigration rhetoric in 1980's and 1990's?

The thesis will first concentrate on the period 1981-1989 when the Polish internal situation intensified migration decisions. A feeling of anxiety, helplessness, humiliation, anger, misery, extremely difficult living conditions and lack of faith in peaceful political solutions pressured Poles to emigrate. Although, as Dariusz Stola writes, martial law restricted Polish international mobility for many years, it also created an extreme sense of readiness to leave the country ${ }^{4}$. The strikes that broke out in Poland during the summer of 1980 immediately drew the attention of world political players who perceived events on Polish soil as the beginning of a new crisis that had shaken the largest European communist country after the Soviet Union. The suppression of the Solidarity movement not only dashed the aroused hopes of people in central Europe, but also made NATO governments concerned about possible serious humanitarian problems. In effect, the vast majority of alliance members, including the U.S., decided to facilitate the legalization of stays for those Poles who could prove oppression because of the imposition of martial law.

I will mainly concentrate on the Refugee Act of 1980, the Immigration Act of 1986 and the Immigration Act of 1990 and their outcomes which, albeit not having a

\footnotetext{
${ }^{4}$ Dariusz Stola, Kraj bez wyjscia?: migracje z Polski 1949-1989 (Warszawa: Instytut Pamieci Narodowej, Komisja Scigania Zbrodni przeciwko Narodowi Polskiemu : Instytut Studiów Politycznych PAN, 2010), 312.
} 
direct connection with the events in Poland, helped to open new paths for Polish immigrants who wished to come to the U.S.. ${ }^{5}$ The Refugee Act of 1980 was the first legislative act that confirmed the official stance of the U.S. towards the refugees on a permanent basis. The act, with its internationally established definition, gave explicit statutory recognition and provided a solid base for the regular reception of refugees, regardless their origin, religion or skin color. Nevertheless, the same legislation also individualized the entrance process for each immigrant as the immigration officers were free to act on their own interpretations of the U.N. protocol relating to the status of refugees $^{6}$. Determining who was a refugee often caused problems. Consequently, Polish immigrant experiences with the Refugee Act 1980 will also show that the concept of political exile and its definition did not always apply to Polish immigrants.

The Act of 1986 (IRCA) will be important in relation to those Poles who had remained in the U.S. illegally, for instance, the so called 'wakacjusze' (migrant workers with tourist visas who prolonged their stay in the U.S.). IRCA was the first and most comprehensive legislation in United States immigration policy to take on the issue of unauthorized migration. It regularized the issue of illegal migrants remaining in the country but at the same time it created enforcement mechanisms to prevent new entries.

I will also present the impact of the Immigration Act of 1990 on Polish inflow to the U.S. This act, while retaining the basic principles of the earlier legislation, was responsible for the most comprehensive change in legal immigration since 1965. Apart from the similar regulations that were found in the old law where legal resident aliens were able to reunite with family members under the second preference, the Act of 1990, for the first time of U.S. immigration history, provided legislation that was based on diversity, excluding at the same time nationalities that had been oversubscribed. The law also created favorable immigration options for Poles.

Nevertheless, in order to understand migration processes, first and foremost, we need to clarify the key concepts and terminology. This will provide a basic framework for the furtherance of an understanding of migration issues presented in this thesis. The

5 Janusz Cisek, Polish Refugees And the Polish American Immigration And Relief Committee (PAIRC,2003), 186

${ }^{6}$ John D. Buenker, Multiculturalism in the United States: a Comparative Guide to Acculturation and Ethnicity (Westport, CT: Greenwood Press, 2005), 338. 
United Nations (1998), in its Recommendations on Statistics of International Migration, revision 1, defines a migrant as "any person who changes his or her country of usual residence. Identifying who is a migrant can be difficult due to the dynamic nature of migration, which in turn implies defining and assessing temporal and spatial criteria."7 Migrants are "those individuals who (1) "belong to a normally migratory culture who may cross national boundaries"; or (2) have left their native country/country of residence "for economic reasons rather than fear of political or ethnic persecution." ${ }^{8}$ Adjectives like "foreign", "international" or "cross-border" indicate that we will be touching upon those migrants who cross the borders from the territory of one state to the territory of another. ${ }^{9}$ J.J. Mangalam states the main aspects of migration, which are: "the physical movement of people in space, relatively permanent change of permanent residence of immigrants and changing professional and social structure." 10 Similar to Aristide Zolberg, he defined the phenomenon of migration as "a relatively permanent transfer of community called migrants from one point to another geographical area, preceded by migrants making process decisions based on a hierarchy of values and objectives"11. In short, we perceive migration as a collective process, reflected in social organization, as well as in cultural terms, as radically changing the way of life, patterns of behavior and symbolic universe of migrants.

International migration is a common phenomenon of international mobility, which includes an entire variety of movements, including those related to a short and very short stay abroad. The U.N. defines an international migrant as "any person who

\footnotetext{
${ }^{7}$ In the 1976 recommendation, a migrant was defined as person who has entered a country with the intention of remaining for more than one year and who either had been in that country continuously for more than one year or, having been in the country at least once continuously for more than one year, must had been away continuously for more than one year since the last stay of more than one involved (United Nations, 1998), 13.

8 DOD, Joint Publication (JP) Foreign Humanitarian Assistance (Washington: Government Printing Office, March 17, 2009)3-29.

${ }^{9}$ Aristide R. Zolberg, A Nation by Design: Immigration Policy in the Fashioning of America (Cambridge, MA: Harvard University Press, 2009), 11.

${ }^{10}$ J. J. Mangalam and Cornelia Morgan, Human Migration: a Guide to Migration Literature in English, 1955-1962 (Lexington, University of Kentucky Press, 1968).30.

11 Z. Mach, "Migracja i społeczne konstruowanie tozsamości," Przeglą Socjologiczny 42/6 (1993) 69.; see also Aristide R. Zolberg, A Nation by Design: Immigration Policy in the Fashioning of America (Cambridge, MA:Harvard University Press, 2009), 13
} 
changes his or her country of usual residence". ${ }^{12}$ Zolberg identifies international migration as an "inherently political process that involves the transfer of a person from the jurisdiction of one state to that of another". ${ }^{13}$ Another important aspect of migration is the duration of stay abroad which is undoubtedly a key feature of migration. In accordance with the U.N. guidelines it is assumed that long-term migration lasts for at least 12 months, and the short-term from 3 to 12 months, though some countries have reduced the latter to two months. Moreover, in many cases, the exact duration cannot be specified due to illegal migration or illegal overstay. It should be noted that the definition of migration, regardless of its length, should be also extended to labor and economic migration which was often entwined with political migration factors in the eighties in Poland. In recent decades, tourism has become the most frequently occurring form of cross-border mobility, yet it is excluded from the migration definition. ${ }^{14}$

It is also crucial for this thesis to be able to distinguish between the concepts of emigration and immigration as the former is understood from the perspective of the sending country by the migrant (country of origin) and the latter is perceived from the perspective of the country to which migrant arrives (target country). Since I mainly analyze an inflow of Polish immigrants from the perspective of receiving country, the terms "immigration" as well as "immigrant" will be important to this study. ${ }^{15}$

The U.S. distinguishes four main types of aliens, that is, the people who are nonU.S. citizens: ${ }^{16}$
a) Legal Immigrants
b) Refugees
c) Temporary Visitors or Non-immigrants

\footnotetext{
${ }^{12}$ United Nations, Recommendations on Statistics of International Migration. Statistical Papers Series M, No. 58, Revision 1. ( New York: Department of Economic and Social Affairs, Statistics Division, 1998), 111.

13 Cheryl Shanks, Immigration and the Politics of American Sovereignty, 1890-1990 (Ann Arbor: University of Michigan Press, 2002), 15.

${ }^{14}$ Stola, Kraj bez wyjscia?, 11.

15 Ibid,11-12.

16 Department of Homeland Security, "The Size and Characteristics of the Unauthorized Migrant Population in the U.S.," Yearbook of Immigration Statistics, accessed online at www.dhs.gov, on Oct. 12, 2006.
} 
d) Unauthorized, undocumented, or illegal immigrants

According to American law, a legal immigrant is "an alien admitted to the U.S. as a lawful permanent resident." According to the Department of Homeland Security, "This is a technical legal term which means a foreign national who has been granted permission to remain in the United States permanently, that is, a legal permanent resident or green card holder and as such is distinguished from a non-immigrant who comes to the United States on a temporary visa." 17 Another definition is presented by the IRS which defines an immigrant as "an alien who has been granted the right by the USCIS to reside permanently in the United States and to work without restrictions in the United States, also known as a Lawful Permanent Resident (LPR). All legal immigrants are eventually issued a 'green card,' which is the evidence of the alien's LPR status." 18 For the purpose of this work, a very broad definition of an immigrant will be used, primarily for the practical reason that the exact data on mobility of Poles during that period is to a certain extent limited, plus there was a vast number of Poles coming to the U.S. on tourist visas with intention to overstay. Thus, a rigid definition of immigration may completely undermine the possibility of using and analyzing the scarce empirical evidence. As the following chapter will indicate, the short-term, temporary or holiday trips had the tendency to transform into an overstayed economic immigration ' $z a$ chlebem" (for bread); they therefore hampered the analysis of statistics of Polish immigration to the U.S. The emphasis in the broader definition is based upon the presumption that an immigrant wished to reside in the U.S. permanently. ${ }^{19}$

Refugees in the U.S. will be defined in accordance with the U.N. definition as persons who are unable or do not wish to return to their home country because of "a well founded fear of persecution due to race, religion, nationality, membership in a

17 “Definition of Terms," accessed January 4, 2014, https://www.dhs.gov/definition-terms\#8.

18 The United States Internal Revenue Service (IRS) accessed January, 2014, https://www.dhs.gov/uslegal-permanent-residents-2011.

19 Permanent residents are also commonly referred to as immigrants; however, the Immigration and Nationality Act (INA) broadly defines an immigrant as any alien in the United States, except one legally admitted under specific nonimmigrant categories (INA section 101(a)(15)). An illegal alien who entered the United States without inspection, for example, would be strictly defined as an immigrant under the INA but is not a permanent resident alien. Lawful permanent residents are legally accorded the privilege of residing permanently in the United States. They may be issued immigrant visas by the Department of State overseas or adjusted to permanent resident status by the Department of Homeland Security in the United States; U.S. Citizenship and Immigration Services, Permanent Resident Alien, Official Website of the Department of Homeland Security, accessed September 12, 2013 from http://www.uscis.gov/tools/glossary/permanent-resident-alien). 
particular social group, or political opinion." ${ }^{20}$ The phenomenon of political exile or refugee status, by its very nature, has an international character, as it contains the essence of forced migration. For this reason, the issue is currently and primarily regulated at the level of intergovernmental arrangements. It will be shown that since 1980 the issue of refugee movements in the United States, to a large extent, became determined by international law, since both rules for granting protection to foreigners, as well as the rights of refugees on the territory of the U.S. resulted from international commitments. The new, international definition of 'a refugee' that the U.S. adopted in 1980 opened a door for many new immigrants from various countries. Some waited in third countries for resettlement in the U.S. and some came directly to the U.S. and requested asylum. The Refugee Act of 1980 for the first time gave the asylum seekers the right to apply for asylum while being in the U.S. Nevertheless, it should be noted that the definition of a refugee does not include the category of so-called economic migrants who left their homelands in order to improve their living conditions. Those foreigners are referred to as voluntary migrants, even if the cause of emigration is extreme poverty and real economic compulsion.

Temporary Visitors or Nonimmigrants are the people who enter the U.S. for a specific time and purpose, for instance business, studying, working or tourism. Unauthorized, undocumented, or illegal immigrants are aliens who reside in the U.S. without valid visas. According to recent statistics there are 11.7 million illegal immigrants in the U.S. ${ }^{21}$ About 55 percent of the total are Mexicans and most entered without being detected across the Mexico-U.S. border. Many temporary visitors become illegal immigrants due to overstaying or violating the terms of their visa by going to work or not departing. The IRS defines an illegal immigrant as an alien who has entered the United States illegally and is deportable if apprehended, or an alien who entered the United States legally but who has fallen "out of status" and is deportable."22

20 Michael Fix and Jeffrey Passel, "Immigration and Immigrants. Setting the Record Straight" (Washington, D.C., The Urban Institute, 1994), 93.

${ }^{21}$ Bruce Drake, "Unauthorized Immigrants: How Pew Research Counts Them and What We Know About Them," Pew Research Center, accessed January 4, 2014, http://www.pewresearch.org/2013/04/17/ unauthorized-immigrants-how-pew-research-counts-them-and-what-we-know-about-them/.

22 Immigration Terms and Definitions Involving Aliens, IRS webpage, accessed January 5, 2014, http://www.irs.gov/Individuals/International-Taxpayers/Immigration-Terms-and-Definitions-InvolvingAliens 
Since this work will focus on the impact of American immigration policies on Poles immigrating to the U.S., it is important to understand the concept of immigration policy. Immigration policy refers to a combination of various policies, targeted to specific groups of migrants: policy on migration (the context of the labor market), integration policy, naturalization policy, and policy towards refugees, repatriation policy, policy on illegal immigrants, and the policy of the state towards its own citizens who return from emigration. Each of these policies has a different logic, mechanisms, goals and purpose. Magdalena Lesinska, in her work, stated that shaping the direction and content of immigration policy can be compared to a game between the state and migrants, where the state establishes its rules and migrants are forced to adapt to them or find existing gaps in order to meet their migration plans. ${ }^{23}$ Tomas Hammar divided the immigration policy concept into two components: immigration control and immigrant integration/immigrant policy, defining the former as the measure to control the influx (entry and stay of foreigners), and the second - the integrating activities geared to those already residing in the country. ${ }^{24}$ Immigration policy, according to Fix and Passel, requires clear separation of three distinct parts of U.S. immigration policy: (1) legal immigration, (2) humanitarian admissions, and (3) illegal immigration. Accordingly, this work in its discussion of Polish immigrants in the 1980's will mostly concentrate on humanitarian admissions and illegal immigration. Discussion of post1989 immigration, however, will focus on legal immigration and the problem of illegal immigrants.

When analyzing U.S. refugee policy, it also will be shown that the distinction between political and economic immigrants from Poland during the communist rule happened to be intricate. This occurred due to the fact that both political and economic motives could coexist and overlap. It cannot be denied that the communist government violated, often openly, human rights. Nevertheless, Polish immigrants who came to the United States as a result of selective persecution constituted only a small part of the total number of immigrants. Moreover, an even smaller portion of political exiles actively participated in political activities while being abroad. All the same, it should be

${ }^{23}$ Magdalena Jasinska, "Migration as an Issue in Contemporary Political Theory and Policy Analysis the Potential Unused," Studia Migracyjne-Przeglad Polonijny (2012), 13.

24 Tomas Hammar, European Immigration Policy: A Comparative Study (Cambridge: Cambridge University Press, 1985), 79. 
noted that the interference of the communist state in all aspects of social life politicized many non-political activities, or at least gave them a political dimension, especially in the context of mass migration due to economic reasons. ${ }^{25}$ Political conditions could have accelerated migration decisions when they resulted in deteriorating economic conditions, which for instance occurred with the dictatorial looting in Haiti ${ }^{26}$ and state dependent development in the Dominican Republic ${ }^{27}$. Agreeing with Marcin Kula, I will indicate that as Polish immigration during the communist era was both economic and political; it was often problematic for the INS when granting political asylum. ${ }^{28}$

The structure of the thesis will contain the following sections: In the first chapter I will briefly outline the evolution of American Immigration and Refugee Policy which, since the beginning of its existence exerted a profound influence on the formation of the American public life -either opening or closing the door for many potential immigrants and cultures that came from all over the world. In the second chapter I will focus on the impact of the U.S. immigration policies on Polish immigrants in the last decade of Polish communism. This chapter will also demonstrate the factors and the character of the departures in 1980's. Moreover, it will be argued that though the political situation and the accompanying atmosphere of fear and uncertainty about the future course of events were important factors, a relatively small proportion of immigrants in this decade could be characterized as 'purely political.' Political turmoil as well as regulations theoretically aimed at refugee applicants accelerated migration tendencies among "economic immigrants." The last chapter is devoted to a discussion of Polish migration tendencies to the U.S. after the collapse of the communist regime in Poland. The collapse of the regime brought greater mobility, choice in employment and though American immigration law no longer accepted Poles under the Refugee Act of 1980,

\footnotetext{
${ }^{25}$ Stola, Kraj bez wyjscia?, 13.

${ }^{26}$ Alex Stepick and Carol Dutton Stepick, "Diverse Contexts of Reception and Feelings of Belonging," Forum Qualitative Sozialforschung / Forum: Qualitative Social Research 10, 3 (September 29, 2009), http://www.qualitative-research.net/index.php/fqs/article/view/1366.

27 Sherri Grasmuck, Between Two Islands, accessed November 26, 2013, http://www.ucpress.edu/book. php?isbn=9780520071506.

${ }_{28}$ The definition of a refugee does not include the category of so-called economic migrants who have left their homeland in order to improve their living conditions. Such aliens are referred to as voluntary migrants, even if the cause of emigration is extreme poverty, creating a real economic compulsion to migrate.
} 
nevertheless the U.S. opened a new door for Polish immigrants with the passage of the Immigration Act of 1990 and a Diversity Visa Lottery. I will show that Poland's political victory over communism created a new economic situation in which the transition to market economy resulted in wage inequality and market instability. Those changes gave Poles another incentive to emigrate again, this time, in the light of continuing democratic reforms in Poland. ${ }^{29}$

29 Jennifer, Hunt "The Transition in East Germany: When is a Ten-Point Fall in the Gender Wage Gap Bad News?" Journal of Labor Economics, Vol. 20,1 ( 2002) 148-169. 


\section{U.S. IMMIGRATION SYSTEM - OVERVIEW}

The history of U.S. immigration reflects the social, economic, and political climate of the time. It also illustrates the nation's ongoing ambivalence about immigration, as well as offers insights on the role of race, prejudice, fear, and nativism in shaping U.S. immigration policy ${ }^{30}$

\section{INTRODUCTION}

U.S. immigration legislation has been an important tool to control the influx of millions of people entering American soil and it is as old as the history of the United States. This chapter will present the evolution of the main U.S. policies toward immigrants. I will show that political and public ambivalence and contradiction towards immigrants have always been present in American immigration policy. Although, immigration to the United States was not numerically restricted or centrally regulated until a hundred years after the founding of the nation, it became explicitly biased against particular nationalities when restrictions on immigration were eventually established. The twentieth century brought the establishment of new specialized agencies, both state and non-governmental, that began to address immigration. Immigration policies in the United States represented simultaneously contradictory values : the humanitarian welcome to "the huddled masses yearning to breathe free" in the inscription on the Statue of Liberty, and acute restrictionism, as embodied in the series of xenophobic immigration laws passed between 1882 and 1924, excluding whole groups as undesirable on grounds of national origin. Although immigration quotas were no longer allotted on the basis of racial categories in the post-World War II period, the U.S. with its cultural and social preferences favored immigration from northern and western Europe.

30 Crizlap,US Immigration Laws,Docstoc.com, accessed January 10, 2014, http://www.docstoc. com/docs/2310082/US-Immigration-Laws. 
Immigration policies answer three fundamental questions: how many, from where, and in what status should newcomers arrive. To better understand the U.S., immigration and refugee policy and Polish immigration to the U.S. it is necessary to provide some basic information about American legislation which underwent three major phases: laissez-faire, qualitative restrictions, and quantitative restrictions.

\section{EARLY LEGISLATION BASED ON EXCLUSIONS}

The beginning of American immigration law dates back to the first years of the new republic, when the Congress established the first regulation for the acquisition of U.S. citizenship (naturalization). According to the Constitution of the United States of 1789 Congress has had exclusive competence in immigration policy matters. During the first hundred years, the U.S. policy toward immigrants had a laissez-faire character, with a system exceptionally open, liberal and scarcely limited. Nonetheless, one must admit that the immigration levels at the time were in fact relatively low: Between 1790 and 1820, only about 100,000 immigrants entered the United States per decade, mostly from the United Kingdom and Western Europe. ${ }^{31}$ The U.S. government was eager to encourage immigration which was also supported by state and local governments and by private companies. ${ }^{32}$ This was mainly due to the fact that the newcomers were perceived as potential soldiers and cheap labor. ${ }^{33}$ This can explain why a third of the regular army soldiers had immigrant backgrounds.

As opposed to the colonial era with no centralized regulation of immigration to North America, the year 1790, that is, after the end of the American Revolution, witnessed the first immigration law which granted national citizenship other than by birth after the period of two years of residence in the United States.

\footnotetext{
${ }^{31}$ Vincent J. Cannato, “Our Evolving Immigration Policy,” National Affairs 13 (Fall 2012): 112.

${ }^{32}$ For instance many investments in America during that time were subsidized by the federal government which not only gave the land to the private companies that built railroads but also supported immigrant influx as potential workers. See (Philip Martin, US Immigration Patterns and Policies, 2011; Vernon Briggs, "Immigration and the U.S. Labor Market: Public Policy Gone Awry," CAHRS Working Paper Series (October 30, 1992), 45, accessed December 5 from http://digitalcommons.ilr.cornell.edu/ cahrswp/328).

${ }^{33}$ Based on the Homestead Act of 1862 free plots of land in the West were offered to the settlers, both immigrants and U.S. citizens, who agreed to live on and develop the land for at least five years; see Walter Ewing, "Opportunity and Exclusion: A Brief History of U.S. Immigration Policy," Immigration Policy Center (2012): 7.
} 
This was the first act regarding the immigration issue at the federal level. Nevertheless, the law limited naturalization to those aliens who were "free white citizens" and had "good moral behavior," leaving out large groups like slaves and Asian immigrants. ${ }^{34}$ In the same decade the American President was granted authorization to deport any foreigner deemed dangerous to the U.S.. In short, the U.S. immigration policy formerly focused more on prescribing who to keep out than who to let in.

In 1875, with the creation of the Office of Immigration the "open door" policy of U.S. immigration came to an end. Instead, we see gentle inflow control based on the principle qualifications such as health, moral, legal and ethnic issues. As the number of late nineteenth century immigrants began to rise, the U.S. Congress propitiously responded to social attitudes toward the newcomers with more qualitative restraints of who could come in. Immigration policymaking began in 1875 with the acts of 1875 and 1882 that constituted the first official exclusion of certain groups based on their origin, such as Chinese contract workers or female immigrants whose purpose was to engage in prostitution. ${ }^{35}$ During the period of qualitative restrictions, the American government not only excluded such groups as homosexuals, "idiots", "feeble-minded persons" or "mentally or physically defective" individuals, but also commenced imposing entry fees or head taxes up to 8 dollars. Nonetheless, until 1920 immigration remained numerically unrestricted. ${ }^{36}$

\section{First Formulation OF a COMPREHENSIVE IMMIGRATION POLICY- INTERNATIONAL LIMITS}

As America hosted more immigrants coming from Eastern and Southern European countries, more racist and anti-immigrant sentiments led to a labeling of newcomers as inferior to Americans. Poland was explicitly listed as a source of such inferior immigrants, as reflected in a speech by none other than Woodrow Wilson, the twenty-eighth president:

\footnotetext{
34 This racial requirement remained in effect until 1952, although naturalization was opened to immigrants from certain Asian countries in the 1940s.

35 The act of 1882 for the first time prohibited immigration from a particular country - China. Immigration from this country was illegal for the next sixty years. The purpose of excluding female prostitutes was to prevent single Chinese women from immigrating and marrying Chinese men already in the U.S., since their U.S.-born infant would have been U.S. citizen: Zolberg, 191.

${ }^{36}$ Shanks, Immigration and the Politics of American Sovereignty, 1890-1990, 32; Zolberg, 214.
} 
"Immigrants poured in as before, but ...now there came multitudes of men of lowest class from the south of Italy and meanest sort out of Hungary and Poland, men out of the ranks where there was neither skill nor energy nor any initiative of quick intelligence, and they came in numbers which increased from year to year, as if the countries of south and east of Europe were disburdening themselves of the more sordid and hapless elements of their population. ${ }^{37}$

Between 1921- 1924, the Congress crafted new legislation that introduced two new and important elements into immigration policy: "(1) control of aggregate immigration through imposition of a ceiling on the total number of immigrants permitted entry, and (2) control of ethnic and national diversity through country-oforigin quotas based on the proportion of each nationality in the U.S. population at the turn of the century." 38 With the passage of the 1921 Quota Act the virtually nonrestrictive character of European immigration turned, almost overnight, into a quota system that would remain in effect until 1965. The movement toward numerical limitations initially reflected a genuine fear of being engulfed by the refugees of warraged Europe. In the 1920's, in response the growing nationalist and isolationist moods of the U.S society, Congress imposed the first quantitative restrictions on immigration, capping overall immigration at about 350,000 and limiting arrivals to 3 percent of the foreign-born persons of each nationality. ${ }^{39}$ Nonetheless, as Claudia Goldin affirms, "More astonishing than the closing of the door in 1921 was that it had remained open despite twenty-five years of assault during which 17 million immigrants from among the poorest nations in Europe found refuge in America." 40

In the light of fear of the negative influences of increasing immigration on the standard of living in the U.S., American citizens of Anglo-Saxon origin influenced the government to establish some of the most restrictive immigration laws. In 1924, the government set an annual limit of 164,000 immigrants, plus accompanying wives and children. The 1924 national origins system was enacted to keep out those who were

\footnotetext{
37 Woodrow Wilson, A History of the American People, vol. 4 (New York: Harper and Brothers, 1901), 212-13.

${ }^{38}$ Elizabeth Rolph, Immigration Policies. Legacy from the 1980s and Issue for the 1990s (Santa Monica CA: RAND, 1992), 43.

${ }^{39}$ Walter A. Ewing, Opportunity and Exclusion: A Brief History of U.S. Immigration Policy, Immigration Policy Center, American Immigration Council, January 2012.

${ }^{40}$ Claudia Goldin is professor of economics at Harvard University, director of the Development of the American Economy Program of the National Bureau of Economic Research, and a research associate of the National Bureau of Economic Research. Claudia Goldin and Gary D. Libecap, The Regulated Economy: A Historical Approach to Political Economy (Chicago: University of Chicago Press, 2008), 7.
} 
described in the legislative records as "the innately inferior new immigrants of eastern and southern Europe." The amount was deliberately weighted in favor of the people of Northern and Western Europe. Each country was granted at least 100 visas out of the total annual number of 154,477 visas. ${ }^{41}$ The result of all these restrictions was to drastically reduce immigration into the U.S. from Eastern European countries, including Poland. The annual quota assigned to Poland amounted to 5,982, and although the Act of 1924 meant a drastic decrease in Polish inflow as a result, Poles still received the highest quota out of all eastern and southern European countries. ${ }^{42}$ The inflow remained small over the next decades because of the restrictions as well as the worldwide depression and WWII. ${ }^{43}$ The system of controls enacted in 1924, based on national origins, remained the foundation of the U.S. immigration law until 1965.

\section{ACT OF 1952 (MCCARRAN-WALter ACT)}

In 1952, Congress passed a new immigration law which to this day is the basis of the U.S. immigration law as it codified and brought together for the first time all the nation's laws on immigration and naturalization. It was a product of the dramatically changed international environment after World War II and the rise of anti-communist attitudes in the U.S. in the early Cold War era.

Although the act retained the national quota system, it expanded its force to all countries except for those in the Western hemisphere, which still had no numerical restrictions imposed. The act maintained the numerical limit of immigrants from the eastern hemisphere at the level of 150,000 per year. The cornerstone of the act was its liberalization of admittance policies for immigrants from Asian countries and reopening of immigration from Japan and other Asian-Pacific countries. ${ }^{44}$ Moreover, it introduced the new system of preferences for families of U.S. citizens, green card holders and skilled workers, putting them into the first preferential group. 50 percent of a country's quota was reserved for those highly skilled workers whose services were in short supply

\footnotetext{
${ }^{41}$ It must be noted that the limits specified in the 1924 act did not apply to immigration from Western Hemisphere countries such as Mexico.

${ }^{42}$ Statistical Abstract of the United States (Washington, D.C: Government Printing Office, 1929), 100.

Accessed December 20 from http://historymatters.gmu.edu/d/5078

${ }^{43}$ Rolph, Immigration Policies, 5.

${ }^{44}$ John J. Bukowczyk, Polish Americans and Their History: Community, Culture, and Politics

(University of Pittsburgh Pre, 2006), 165.
} 
among the native labor force, while another 20 percent was set aside for the spouses and unmarried adult children of permanent resident aliens. ${ }^{45}$ Nevertheless, though the act allocated 170,000 visas to countries from the Eastern Hemisphere, 70 percent of all immigrant slots were allotted to the natives of just three countries - United Kingdom, Ireland and Germany - and went mostly unused, whereas there were long waiting lists for the small number of visas available to those born in Italy, Greece, Poland, Portugal, and elsewhere in eastern and southern Europe. ${ }^{46}$

In short, we may conclude that The McCarran-Walter Act softened the immigrant restrictions based on race, and created the foundation for current immigration law, but at the same time it kept the racialized immigration quota system in place and introduced new ideological grounds for exclusion. The ethnic quota system, established in 1924, still remained in force and again only immigration from Western Hemisphere countries continued to be unlimited.

\section{IMMIGRATION ACT OF 1965 - THE OVERALL VISA LIMIT}

It was not until 1965 that the U.S. decided to enact the Immigration Reform Act that abandoned numerical restrictions on immigrants in terms of race and national origin. It was considered to be a symbolic act, an extension of civil rights sentiments beyond U.S. borders. Immigration and Naturalization Act Amendments introduced changes to the McCarran-Walter Act by replacing the system of national quotas with fixed general annual limits. In short, the act of 1965 established the basic structure of today's immigration law where family reunification became the cornerstone of U.S. immigration policy. For the first time, it gave higher preference to the relatives of American citizens and permanent resident aliens than to applicants with special job skills. With the increasing pressure of population in Latin America the act for first time limited immigration from the Western Hemisphere and set the total limit at 120,000, whereas the number of immigrants from Eastern Europe remained set at 170,000. Washington also decided to introduce a ceiling of 20,000 for each country and a seven-

\footnotetext{
${ }^{45}$ Ira J. Kurzban and American Immigration Law Foundation, Kurzban's Immigration Law Sourcebook: A Comprehensive Outline and Reference Tool (Washington, DC: American Immigration Law Foundation, 2002), 3.

46 "Three Decades of Mass Immigration: The Legacy of the 1965 Immigration Act," Center for Immigration Studies, accessed December 4, 2013, http://cis.org/1965ImmigrationAct-MassImmigration. http://www.upa.pdx.edu/IMS/currentprojects/TAHv3/Content/PDFs/Legacy_Immigration_Act_1965.pdf
} 
category system. The elimination of the national quota system and an increased support for the two pillars - family and work migration- has led to a steady increase of the number of people immigrating to the United States (including the increase in the number of illegal immigrants) and transformations within the ethnic composition of the inflow. Under the National Immigration Act of 1965, up to $60 \%$ of the visas have been granted for the relatives of U.S. citizens, 6\% - for asylum seekers and 30\% - for job seekers. ${ }^{47}$ Nevertheless, when we look at the Polish contribution to those numbers we will see that Poles, similar to the Irish and Italians, became adversely affected by the shift toward the Asians and Latinos. As Geoffrey Levey affirms, moving from the system of national quotas to immigration policy based on family reunion had the unintended effect, inter alia, of enabling more Asians and Latin Americans to apply for the immigrant visas than Europeans. The rate of immigration "take up" of those affected European countries for the period 1965-1985 was lower than for the period 1953-1965.

\section{THE EVOLUTION OF U.S. REFUGEE POLICY}

We must note that until 1980 the U.S. had no systematic policy with respect to refugees. Before then, the U.S. administration enacted different laws based on various loopholes in the law to parole people seeking asylum. ${ }^{48}$ Regarding U.S. immigration policy in the aftermath of World War Two, it was primarily unfavorable for the refugees. The United States with its anti-immigrant legislation (Act of 1924) initially did not offer refugee programs that could adopt large number of people seeking asylum. Congress still functioned within a framework of ethnocentric attitudes of established inhabitants toward the immigrants. Nevertheless, American society, encouraged by the efforts of numerous ethnic groups, began to alter its initially hostile attitude toward their proposals that the U.S. accepts its share of war victims. The prevailing immigration policy mainly rested on economic concerns and domestic pressures, whereas immediately following in World War Two, it took into consideration humanitarian and

\footnotetext{
${ }^{47}$ Debra L. DeLaet, U.S. Immigration Policy in an Age of Rights (Westport, CT, Greenwood Publishing Group, 2000), 78 .

48 The Hungarian Paroles Act of 1958, the 1966 Cuban Adjustment Act or the 1975 Indochina Migration and Refugee Asisstance Act are cases in point.
} 
foreign policy concerns with regards to refugee flows. In Zolberg's Nation by Design it can be found that the U.S. took the issue of displaced persons and refugees as symbolic of the problems of living under communism and saw the departure of refugees as a means of weakening communist regimes. ${ }^{49}$ Nevertheless, we must remember that although the postwar concept of refugee in U.S. immigration policy developed into a distinct formal category in the U.S. legal system, the discord between humanitarian and instrumentalist incentives continued. For instance, the U.S. took part in the drafting, but did not ratify the 1951 UN Refugee Convention. The U.S. preferred to admit limited categories, defined by its own political priorities, and based its refugee policy on paroles and exceptions to the national origins quota system.

The "parole power" regarding to the refugee groups had been designed originally as an exception to the normal immigration process in order to facilitate the entrance of individual aliens for "emergency" humanitarian reasons. ${ }^{50}$ For instance, such parole practices helped to admit those who fled "communist oppression" while providing little relief for those leaving other parts of the world, especially countries considered U.S. allies. The first major paroles were the 1948 Displaced Persons Act and the 1952 Refugee Relief Act. The Displaced Persons Act of 1948 allowed in more than 400,000 Europeans. The Refugee Relief Act of 1953 permitted the admission of another 190,000. As for the numerical contribution of Poles on the basis of the first act, 110,566 Poles came to the U.S. ( $30 \%$ of total inflow) ${ }^{51}$, and based on the 1952 act the number of Poles amounted 19,430. In total, more than 200,000 Polish political exiles and displaced persons were admitted to the U.S. from 1945 to $1969 .{ }^{52}$ Parole power became the major tool for the refugee admissions until the 1980 Refugee Act. It was also used for Hungarians in 1956, for Cubans in the 1960s and 1970s, and for Russian Jews and the Indochinese in the late 1970s. ${ }^{53}$

\footnotetext{
${ }^{49}$ Aristide R. Zolberg, "From Invitation to Interdiction: US Foreign Policy and Immigration since 1945" in Michael S. Teitelbaum and Myron Weiner eds. Threatened Peoples, Threatened Borders: World Migration Policy.( New York: The American Assembly, Columbia University, 1995)117.; Gil Loescher and John A. Scanlan, Calculated Kindness (Detroit: The Free Press, 1998), 59.

${ }^{50}$ Deborah Anker, "U.S. Immigration and Asylum Policy: A Brief Historical Perspective", In Defense of the Alien 13 (January 1, 1990): 78.

${ }^{51}$ Bukowczyk, Polish Americans and Their History, 160.

52 Mary C. Waters, Reed Ueda, and Helen B. Marrow, The New Americans: A Guide to Immigration Since 1965 (Cambridge, MA: Harvard University Press, 2007), 571.

${ }^{53}$ Anker, "U.S. Immigration and Asylum Policy," 78.
} 
As part of the 1965 immigration act, the U.S. enacted a permanent refugee quota, yet as a seventh preference to numerical limitations, and defined a 'refugee' exclusively as one fleeing a communist or communist-dominated country. ${ }^{54}$ Such a situation highlighted contradictions between domestic law and the U.N. definitions of a refugee. Nonetheless, the U.S., dissatisfied with the ad hoc nature of the parole power and limited congressional authority along with increasing worldwide refugee concerns resulting from the Haitian crisis and Vietnam War, decided to introduce the Refugee Act of 1980. The new legislation reduced the costs involved in dealing with the problem that were dumped upon the states, local communities and voluntary agencies. The new law created a path for admission to the U.S. by establishing a formal and simplified procedure of asylum. ${ }^{55}$ The Refugee Act of 1980 introduced into U.S. law the international definition of refugee, much wider than the previous ones as the U.S. decided to adhere to international standards. As defined by the Refugee Convention of 1951 (including the Additional Protocol of 1967) a refugee is a person who:

"owing to a well-founded fear of being persecuted for reasons of race, religion, nationality, membership of a particular social group or political opinion, is outside the country of his nationality, and is unable to or, owing to such fear, is unwilling to avail himself of the protection of that country or return there because there is a fear of persecution." ${ }^{56}$

In the words of Senator Ted Kennedy, the Refugee Act of 1980 was "the single most significant reform of our Nation's immigration statute in 15 years giving a statutory meaning to the national commitment to human rights and humanitarian

\footnotetext{
${ }^{54}$ Deborah Anker and Michael Posner, "The Forty Year Crisis: A Legislative History of the Refugee Act of 1980," San Diego Law Review 19,1 (December 1981): 17. Refugees, defined by the Immigration and Nationality Act as amended were aliens... "(A) that (i) because of persecution or fear of persecution on account of race, religion, or political opinion they have fled (I) from any Communist of Communistdominated country or area, or (II) from any country within the general area of the Middle East, and (ii) are unable or unwilling to return to such country or area on account of race, religion or political opinion, and (iii) are not nationals of the countries or areas in which their application for conditional entry is made; or (B) that they are persons uprooted by catastrophic natural calamity as defined by the President who are unable to return to their usual place of abode...." (Section 203(a) (7)

${ }_{55}$ Piotr Korcelli, "International Migrations in Europe: Polish Perspectives for the 1990s," International Migration Review 26, no. 2 (July 1, 1992): 60, doi:10.2307/2547058.

${ }^{56}$ Remigiusz Bierzanek and Janusz Symonides, Public International Law, LexisNexis (Warszawa, 2002), 259. See http://www.unhcr.org/3b66c2aa10.html.
} 
concerns." The admittance of refugees, he said, was "a fundamental human rights issue." $" 57$

\section{CONCLuSion}

This section has shown that the U.S. immigration policy underwent tremendous changes since the U.S. was founded. We can see that the former U.S. attitude toward immigration was not centralized and was rather focused on a relatively open reception of newcomers during the 18th and early 19th centuries with certain national and social exclusions of who could come in. Nevertheless, with worsening economic conditions, nativist moods and increasing number of immigrant inflows the U.S. passed more restrictive immigration legislation. This, in turn, adversely affected Eastern European immigration with the most significant numerical restrictions based on the national origins. Although, the act of 1965 was admirable in ending discrimination against immigrants based on national origins, the southern and eastern Europeans who were expected to benefit from the 1965 law remained relatively unequal in the immigrant pool compared to residents of northern and western Europe.

57 Richard M. Weintraub and Christopher Dickey, "Vietnam Offers to Let 10,000 Leave Monthly," Washington Post (Washington, May 16, 1979), A1. 


\section{Polish Political ImMigration in The 1980'S}

\section{INTRODUCTION}

This chapter will aim to analyze Polish immigration in the U.S. in the context of American immigration policy during the last decade of communism in Poland and outline the U.S. political response after the enactment of martial law in Poland in December 1981. Firstly, I will present a discussion of the push factors, affirming that despite the Polish government's reduction of people's international mobility, this also caused the highest preparedness to migrate and willingness to remain in the visiting country since 1958. Secondly, I will focus on the impact of American immigration laws on Polish newcomers in the U.S., with a particular concentration on Polish refugees and answer the question whether American immigration policy was favorable to Polish immigrants. The dramatic events in Poland accelerated the decision to choose life in exile, but the political upheaval that occured in Poland also had an impact on immigration procedures for Poles to the U.S. and other countries.

\section{INTENSIFICATION OF MIGRATION DETERMINANTS AFTER MARTIAL LAW}

In the summer of 1980 Polish society faced a previously inconceivable stage of euphoria. As a result of the social climate in Poland, an Independent Self-Governing Trade Union "Solidarity" was formed [this strange name meant "Free Trade Union", but the word Free was avoided not to irritate the communists]. Many Poles as well as foreign political actors at that time expected significant internal changes in Poland. Nonetheless, martial law, imposed on 13 December 1981, crudely interrupted this opportunity. Despite the fact that martial law caused a significant drop in international mobility $^{58}$, it also contributed to the increased number of emigration decisions. ${ }^{59}$ According to Dariusz Stola, at least 150,000 Poles decided to stay in western countries and wait the situation out. Most of the Poles who were at that time residing abroad decided not to return to Poland, which was reflected in the number of application

\footnotetext{
${ }^{59}$ In Stola's account we further read that though the emigration statistics went down to a minimum, the socio-political situation in Poland intensified the processes that increased migration. Closed borders lead to the claustrophobic sensation that accelerated future emigration decisions.
} 
submissions for political asylum. ${ }^{60}$ As Paweł Kaczmarczyk affirms, martial law restrictions contributed to the increased migration potential, which resulted in a mobility explosion. $^{61}$

Emigration in the 1980s is often seen primarily through the prism of the political situation in Poland. Referred to as the "Solidarity emigration", this suggests its close relationship with the trade union and the movements against the communist regime in the early 1980 s.

In the atmosphere of socio-political conflict in Poland, the Polish communist government adopted a forced emigration policy against more vocal activists. The Communist regime practically made an offer that had a "cannot refuse" character. ${ }^{62}$ The most characteristic group of political exiles was undoubtedly the internees and other trade unionists compelled to leave the country by Polish security forces. The government thus intended to get rid of individuals who were potentially threatening and ominous to the socio-political order. ${ }^{63}$ The Polish government issued passports with a note that the immigrant had the right to cross the Polish border only once. Although passports had a convertibility clause into consular passports, Polish authorities deliberately kept those passports valid for a year or two to prevent passport holders from returning to the country. As Dariusz Stola notes, it was a kind of "one-way ticket." Permission to emigrate meant a refusal to return and those "one way- ticket holders" forced to leave Poland faced severe consequences of an administrative, legal and political character. This was perceived as a specific form of (temporary) banishment, punishment generally rejected by international law, in violation of Art. 13 of the Universal Declaration of Human Rights (Every person has the right to return to his country). ${ }^{64}$

Even so, it must be noted that though the political situation and the accompanying atmosphere of fear and uncertainty about the future were essential push

${ }^{60}$ Stola, Kraj bez wyjscia?, 312.

61 Paweł Kaczmarczyk, Migracje zarobkowe Polaków w dobie przemian (Warsaw: Wydawnictwa Uniwersytetu Warszawskiego, 2005), 123.

62 Badasu, Polish Immigration to Alberta since 1980, 51-52. Matejko, 'Polish Canadians in the 1980's: Issues and Problems', 90-93.

63 Władysław Misiak, Nowa Emigracja $i$ Wyjazdy Zarobkowe Za Granice (Wrocław: Polskie Towarzystwo Socjologiczne, 1991), 123-143.

${ }^{64}$ Stola, Kraj bez wyjscia?, 317. 
factors, only a relatively small proportion of immigrants during this decade could be characterized as purely political. ${ }^{65}$

Aside from the political determinants, the aforementioned high readiness to leave the country was mainly related to the way the socialist economy functioned. Difficult living conditions under communist rule had a negative impact on an entire generation of young people who did not favorably perceive the country's prospects and opportunities for a career. The collapse of hope and faith in a peaceful political solution and the economic problems after the collapse of the "Solidarity" were the most significant push factors. ${ }^{66}$ An inconsistent and ineffective socialist economy with permanent shortages of basic necessities and the underdevelopment of trade between the countries of the communist bloc had a negative impact on the living conditions of the average citizen. ${ }^{67}$ Indeed, this situation was a source of strong long-term stress and no doubt it had an impact on potential immigrants. The decline in real income, the lack of goods and lines in stores caused social dissatisfaction. ${ }^{68}$

As observed by sociologists studying Polish society, the sudden slump of the material well-being was the most severe in the years 1980-1982 and had a traumatic nature due to the rapidity and depth of the decline. ${ }^{69}$ In short, all the aforementioned factors contributed to an explosion of popular discontent at the beginning of the decade of the 1980s, which led to an intensification of migration factors. ${ }^{70}$ According to the survey conducted by Stefan Nowak in 1983, every third person was a prospective immigrant. Nowak added: "(...) this is the strongest social frustration measure in our (Polish) country". ${ }^{71}$

One cannot also forget that the migration decisions also resulted from other individual factors, often irrational or a private and emotional nature. They were associated on the one hand with individual predispositions (such as willingness to take

\footnotetext{
${ }^{65}$ Janusz Cisek, Polish Refugees..., 186.

${ }^{66}$ Stola, Kraj bez wyjscia?, 324.

${ }^{67}$ Malgorzata Krywut-Albanska, "Przyczyny i Okoliczności Emigracji z Polski w Latach 1980. Na Przykładzie Emigracji Do Kanady,” Centre of Migration Research (2011): 3.

${ }^{68}$ Kaczmarczyk, Migracje zarobkowe Polaków w dobie przemian, 123.

69 Mirosława Marody, Co Nam Zostało z Tych Lat... Społeczeństwo Polskie u Progu Zmiany Systemowej. (London: Aneks, 1991), 234.

${ }^{70}$ Ibid., 234-245.

${ }^{71}$ Stefan Nowak, Społeczeństwo Polskie Czasu Kryzysu (Warsaw: UW IS, 1984), 59.
} 
risks, adventure, curiosity), but also the general atmosphere of the 1980s, which can be described as a kind of "migration fever."72

\section{POLISH IMMIGRATION TO THE U.S. IN NUMBERS}

Before we look at American immigration policy toward Polish immigration to the U.S. it is crucial to outline the statistics of Polish immigration. Some could argue that the inflow of Polish refugees after the overthrow was not impressive. For instance, between 1975 and 1981, 6,078 Poles arrived in the U.S. as refugees and 355 as asylum seekers. The total number amounted to 6,433 people. In the year 1982, that is just after the suppression of the "Solidarity movement", the number reached 7,504 refugees and 200 asylum seekers. A year later, the number of Poles was lower, 4,625 refugees and 805 asylum seekers, giving a total of 5,430 people. By comparison, 131,139 Asians came to the United States in 1981 and the U.S. government at the same time granted 33,000 requests for political asylum from the Soviet Union, out of which 13,444 were used. ${ }^{73}$ However, when we look at the statistical picture between 1982 and 1987 compared to other central and eastern European countries we will notice that Poles remained the most numerous group with $25,783 .{ }^{74}$

Table 1 -Refugees from Central and Eastern Europe in the United States in years 1982- 1987

72 Janusz Rymarczyk, Migracja Sity Roboczej Do Krajów EWG i Jej Konsekwencje Spotecznogospodarcze (Poznań: Instytut Zachodni, 1986),58.

${ }^{73}$ Cisek, Polish Refugees and the Polish American Immigration and Relief Committee., 188.

${ }^{74}$ Sakson, "Po Drugiej Stronie Oceanu. Nowi Emigranci z Polski w Metropolii Chicagowskiej," 15. 


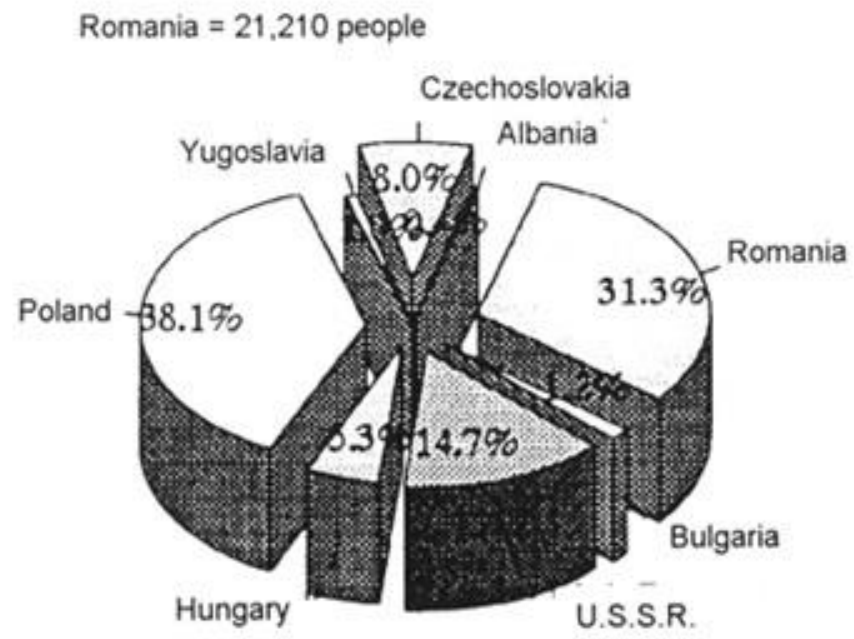

Source: U.S. Immigration and Naturalization Service, Statistical Yearbook of the Immigration and Naturalization Service, 1999, Washington, D.C.: U.S. Government Printing Office, 2002.

One must also note that the number of all Polish immigrants to America did increase when compared to the immigration statistics of the earlier decades. ${ }^{75}$ For instance, the number of legal Polish immigrants in the years 1971-1980 amounted to 43,600, whereas the number of legal Polish immigrants in the years 1981-1990 reached 97,400 , i.e. it more than doubled. ${ }^{76}$ The non-immigrants constituted, according to Erdmans' calculations, nearly 450,000 in the 1980's out of which almost 80 percent of those came as temporary visitors for pleasure. ${ }^{77}$ Likewise, when we look at the total number of Polish refugees, we will see that it reached the approximate number of 33,889 and that constitutes $69.6 \%$ the total amount of Polish refugees in the U.S. between 1961 and 1992. ${ }^{78}$

\footnotetext{
75 United States Dept of State Bureau for Refugee Programs, Department of State Bureau for Refugee Programs Orientation Manual (United States Dept. of State, Bureau for Refugee Programs, 1986), 25.

76 U.S. Immigration and Naturalization Service, Statistical Yearbook of the Immigration and Naturalization Service, 1999, (Washington, D.C.: U.S. Government Printing Office, 2002)

${ }^{77}$ Erdmanns, Opposite Poles, 63.

${ }^{78}$ Ibid., 64.
} 
The report for the fiscal year 1981 prepared by the "Refugee Resettlement Office" and Social Security Administration to Congress on January 31, 1982 could already confirm the intensification of the migration flow:

"Poland, since August 1980, the number of people seeking political asylum has quadrupled. The refugee camps in Europe, particularly in Austria are swelling with Polish refugees, and there is no relief in sight; if anything, their numbers will increase this coming year. The PAIRC ${ }^{79}$ has already experienced a significant increase in the latter part of 1981. Usually, the agency alone handles about 300 refugees a year. In the period 1980/1981, out of total of about 4,000 Polish refugees entering the U.S.A, 458 were relocated by the PAIRC. At the present time there are about 15,000 Poles awaiting emigration visas, mostly to the United States, and that number is sure to continue to grow as long as the situation in Poland does not improve. The PAIRC most certainly is prepared to handle its share." 80

The New York Times wrote about the intensification of Polish immigration as well. According to the notes appearing in the edition of April 7, 1981 1,400 Poles awaited asylum in Austria ${ }^{81}$ in the first quarter of 1981. It has been calculated that the Poles were the majority of refugees:

"The Intergovernmental Committee for Migration, which is involved in the resettlement of refugees, said the Poles made up the majority of the 1,678 East Europeans who registered from January through March. (...) In the first three months of last year, 650 East European refugees registered in Austria." 82

This shows that the U.S. federal government was aware of the impending wave of refugees regardless of the direction which events could have gone as indicated by the date of the document. When looking at these statistics one must remember that out of

79 Polish American Immigration and Relief Committee - founded in 1947, was the organization responsible for the relocation of displaced persons. The committee continued its work during the Cold War era, and in the last decades of communism in Poland when Poles continued to flee the communist regime.

${ }^{80}$ Refugee Resettlement Program. Report to the Congress, January 31, 1982, p.61.

${ }^{81}$ Austria was perceived to be the biggest sanctuary for Polish refugees providing provisional shelter while they were waiting to fly to other countries, mainly the U.S.,Canada and Australia; “Austria Finds Polish Inflow a Burden,” New York Times, January 10, 1982, http://search.proquest.com.www.libproxy.wvu.edu/hnpnewyorktimes/docview/122128207/abstract/14219 B307042430B287/5? accountid=2837).

82 „Austria Cites Doubling in Number of Polish Refugees in Last Year”, The New York Times,( April 7, 1981). 
total number of Polish refugees who arrived in America from 1981 to the end of May 1986 , only about 3,000 , or $10 \%$ of the total number, were members of the Solidarity. ${ }^{83}$

\section{AMERICAN REACTION TOWARD THE IMPOSITION OF MARTIAL LAW IN POLAND AND THE IMPACT OF IMMIGRATION POLICIES ON POLISH IMMIGRANTS}

Martial law in Poland caused a huge reaction and response from the world. State authorities and leaders of many democratic countries firmly and strongly condemned the military action against the Polish people. ${ }^{84}$ The Atlantic Council reacted and recommended that United States and other NATO members impose economic sanctions against the communist regime. ${ }^{85}$ At a press conference on December 17 the U.S. President Ronald Reagan gave a speech that condemned internal repressions in Poland. Furthermore, on January 30, 1982, the President announced and proclaimed a day of solidarity with the Polish nation and the U.S. government sponsored a TV program on martial law in Poland which was meant to give a clear sign of support for Solidarity. ${ }^{86}$ Furthermore, the President agreed that the political reprisals of the Polish regime were a violation of the Helsinki Final Act and as a consequence, the U.S. suspended economic aid to Poland until martial law was lifted. A few days later, on December 22, the U.S. Ambassador in Warsaw Francis Meehan informed Foreign Minister Jozef Czyrek that the U.S. government would impose financial measures. ${ }^{87}$ The U.S. suspended loan guarantees to the Export-Import Bank and emphasized its opposition to the admission of Poland to the International Monetary Fund. Nevertheless, it must be noted that the sanctions imposed on the Polish government were not as extensive as planned. The reason for this was the knowledge that a significant deterioration in the economic situation in Poland could have affected the economies of other countries. The Polish government was in debt to many western banks and its default could have led to serious

${ }^{83}$ Cisek, Polish Refugees and the Polish American Immigration and Relief Committee, 210.

${ }^{84}$ Janusz Rymarczyk, Migracja Siły Roboczej Do Krajów EWG i Jej Konsekwencje Społecznogospodarcze (Poznań: Instytut Zachodni, 1986).

${ }^{85}$ Beverly Crawford, Economic Vulnerability in International Relations: East- West Trade, Investment, and Finance (New York:Columbia University Press, 2013), 161.

${ }^{86}$ The program was attended by the most famous names in global culture, including Kirk Douglas, Max von Snydow, Henry Fonda,Paul McCartney, Czeslaw Milosz, and even Frank Sinatra, who sang part of his song in the Polish language.

87 Arthur R. Rachwald, In Search of Poland: The Superpowers' Response to Solidarity, 1980-1989 (Stanford: Hoover Press, 1990), 63-68. 
problems in the entire Western banking system. Moreover, Reagan believed that harsher sanctions would have irreversible consequences on Polish-U.S. relations. ${ }^{88}$

As a consequence of Poland's internal turmoil, the U.S. interrupted air connections between Chicago and Warsaw, and soon the American authorities, as part of the sanctions imposed on the communist regime, banned LOT Polish Airlines aircraft from landing at all U.S airports. Trips to the U.S. were possible only on the aircraft of other carriers, with transfers from airports in Europe or Canada, where LOT Polish Airlines still operated. Despite the fact that only a few Poles left communist Poland in the first days after the imposition of martial law (among them there was a group of seventy-two Americans of Polish descent who flew to New York with LOT airlines), ${ }^{89}$ at least 150,000 Poles decided to stay in western countries and wait the situation out. Polish political turmoil also had an impact on tourist inflow from America to Poland, and the tourist trade between Poland and the U.S. drastically decreased. Already in the autumn of 1980, the Embassy of Polish People's Republic in Washington reported that due to the threat of Soviet intervention the U.S. government had almost completely inhibited U.S. citizens' travel to Poland." 90

We must remember that despite those aforementioned sanctions and prohibitions, Polish political and economic turmoil confronted U.S. and other NATO members with a humanitarian problem. Thus, the vast majority of member states decided to facilitate the legalization of stay for Poles, who had been surprised by the imposition of Martial Law while abroad. As the decade of 1980's raised again the issue of Polish political migrants, first and foremost it is crucial to outline the U.S. immigration policy and American response toward Polish refugees and political immigrants.

\section{IMPACT OF THE REFUGEE ACT OF 1980 ON POLISH NEWCOMERS}

More than a year before the imposition of martial law in Poland, on March 17, 1980 the U.S. government decided to initiate new legislation with regards to refugees. The Refugee Act of 1980 (Public Law 96-212) constituted the first piece of legislation

\footnotetext{
${ }^{88}$ Ibid.,65.

${ }^{89}$ Cisek, Polish Refugees and the Polish American Immigration and Relief Committee, 189.

${ }^{90}$ Ibid., 190.
} 
that adopted on a permanent basis the international definition of a refugee established by the 1951 United Nations Convention Relating to the Status of Refugees. The Refugee Act provided, for the first time, a statutory entitlement to claim political asylum. ${ }^{91}$ As mentioned in the first chapter, all the previous laws had a temporary character and were addressed to a specific geographical direction or to a specific group of refugees.

The Refugee Act stated that every alien who was within any of the regions/countries designated to be a special humanitarian concern to the U.S. was eligible for refugee status if he/she could prove a "well-grounded fear based on race, religion, nationality, membership in a particular social group, or political opinion." 92 Another important aspect of the Refugee Act of 1980 with regards to Poles was that an alien could apply for political asylum in the U.S. irrespective of immigration status, for instance whether or not he or she held legal immigrant documents. Thus those Poles who overstayed in the U.S. during that time or arrived to the U.S. on tourist, business, and student visas had a chance to apply for political asylum while in the U.S. The new refugee definition intended to eliminate the immigration bureaucracy's bias against refugees from hostile countries. ${ }^{93}$ Most importantly, the law of 1980 tended to provide a solid basis for the regular reception of refugees, regardless of their origin, religion and skin color. An interesting stipulation of the new regulation was that it provided the two immigration modes for refugees. The first, the so-called normal mode, assumed a ceiling for immigrant inflow for the period 1980-1982 of 50,000 newcomers. But in each of these years the U.S. president had the right to increase the number depending on the urgency of circumstances. The Act of 1980 abolished the distinction between western and eastern hemisphere giving an overall ceiling of 270,000 immigrants per year. It is worth remembering that after 1965, refugees were admitted as "seventh preference" immigrants, and were given 6 percent of the total slots available to immigrants. The Refugee Act of 1980 erased the seventh preference category and began

\footnotetext{
${ }^{91}$ Arthur C. Helton, "Political Asylum Under the 1980 Refugee Act: An Unfulfilled Promise," In Defense of the Alien 6 (January 1, 1983): 23.

92 Deborah Anker, "The Development of U.S. Refugee Legislation," In Defense of the Alien 6 (January 1, 1983): 163.

93 Barbara M. Yarnold, "Politicized Judicial and Congressional Asylum Policymaking, 1980-1987," The Justice System Journal 17, no. 2 (January 1, 1994): 209.
} 
admitting refugees on a standardized basis according to the international definition of a refugee. ${ }^{94}$

The new refugee regulation in 1980 in the U.S. did not have a direct connection with the events in Poland, but the U.S. government foresaw the possibility of certain adjustments in extraordinary circumstances such as those Poland faced. The President could establish an additional number of refugees admitted to the U.S. for the next period (not exceeding 12 months) in response to exceptional humanitarian needs, and the right of entry could be granted to those refugees who required special care. ${ }^{95}$ From the Polish point of view it was important to persuade the U.S. President to increase the number of authorized immigrants to more than 50,000 per year. ${ }^{96}$ On the basis of this provision, the leaders of Polish American communities urged the President to declare an "emergency refugee situation," which under the Refugee Act of 1980 Poles would receive an additional number of refugee slots. PAIRC, on behalf of Polish immigrants, also called upon the President to facilitate the granting of political asylum, the right to employment and modified treatment by the U.S. immigration officials. ${ }^{97}$ On that basis, President Reagan allowed those Poles to remain in the United States who had arrived in the U.S. before December 13, 1981, and who had demonstrated the will not to return to Poland. It is important to note that the Refugee Act of 1980 offered language and job training, as well as a housing allowance and food stamps. In the mid-1980s, a refugee could receive assistance for up to 36 months after arrival." 98 Moreover, the newly arrived immigrants could take an English-as-a-Second-Language (ESL) course. It is also worth noting that in those states where the number of immigrant minorities was

\footnotetext{
${ }^{94}$ Erdmans, Opposite Poles, 63.

${ }^{95}$ Cisek, Polish Refugees and the Polish American Immigration and Relief Committee, 184.

96 „If the President determines, after appropriate consultations, that (1) an unforeseen emergency situation exists, (2) the admission of certain refugees in response to the emergency refugee situation is justified by grave humanitarian concerns or is otherwise in the national interest, and (3) the admission to the United States of the refugees cannot be accomplished under subsection (a), the President may fix a number of refugees to be admitted to the U.S. during the succeeding period (not to exceed twelve months) in response to emergency refugee situation and such admissions shall be allocated among refugees of special humanitarian concern to the United States in accordance a determination made by the President after the appropriate consultation provided under this subsection. See Immigration and Nationality Act with Amendments and Notes on Related Laws, Committee on the Judiciary (Washington, D.C.: House of Representatives, United States, U.S. Government Printing Office, 1980), 172.

97 Joanna Wojdon, “W jedności sita”: Kongres Polonii Amerykańskiej w latach 1968-1988 (Toruń: Wydawnictwo Adam Marszałek, 2008), 436.

${ }^{98}$ Geraldine Balut Coleman, "Educating Polish Immigrants Chicago Style: 1980-2002," Polish American Studies 61, no. 1 (April 1, 2004): 28.
} 
high, the schools offered the children of newly admitted immigrants bilingual classes. ${ }^{99}$ Nevertheless, apart from what the provisions of the act offered to Poles, many of them became subsequently disillusioned with unsatisfactory jobs, layoffs and so forth. ${ }^{100}$ As Cisek affirms, many Poles, upon arrival, had an image of the United States that was too optimistic. Some expected free hotel accommodation and employment for exorbitant hourly rates, despite their poor English language skills and lack of professional qualifications. In addition, not all could find jobs in their professions. ${ }^{101}$

\section{EVD (EXTENDED VOLUNTARY DEPARTURE) AND POLISH IMMIGRANTS}

In addition to the Refuge Act of 1980, the U.S. introduced a temporary protection (the so-called EVD or Extended Voluntary Departure) for those foreigners who did not qualify for asylum but whom U.S. authorities were unwilling to deport. The U.S. offered a limited sanctuary to foreigners whose country had an emergency situation. ${ }^{102}$ Likewise, in the case of the Poles, immediately after the introduction of martial law, the U.S. assigned EVD status to those Poles who had been in the U.S. and whose visa had expired. The Extended Voluntary Departure was first applied to nonimmigrant Poles on December 23, 1981, when martial law was declared. EVD status was executed by the Executive Office for Immigration Review (EOIR) that decided who to give the right of a three-month stay under this status, which could be extended. In the Polish case, EVD was renewed regularly and its legal force covered those Polish newcomers who arrived through mid-1984. Although, martial law was lifted on 31 December 1982, the Department of State still continued to advocate EVD for Poles for various reasons: they might have faced retaliation for having been in the

\footnotetext{
99 The U.S. Congress had passed the Bilingual Education Act in 1968, the Illinois General Assembly activated it in 1973, and the U.S. Supreme Court upheld it in 1974. Even though the Bilingual Education Act of 1968 has been amended several times since 1968, it has endured and continues to provide federal funding for bilingual education programs, which include teacher training, bilingual and ESL programs, a variety of language immersion and experimental programs, and academic research. However, it was not until 1978 that Polish-speaking students were included in any bilingual program offered by the Chicago Public Schools. Geraldine Coleman, "Educating Polish Immigrants Chicago Style:1980-2002" Polish American Studies 61(1), 27-38.

100 David W. Haines, Refugees in America in the 1990s: A Reference Handbook (Westport, CT: Greenwood Publishing Group, 1996).

${ }^{101}$ Cisek, Polish Refugees.,200-205.

102 Lynda J. Oswald, "Extended Voluntary Departure: Limiting the Attorney General's Discretion in Immigration Matters," Michigan Law Review 85, no. 1 (October 1, 1986): 152-190.
} 
U.S., NATO alliance unity required continuing a no-deportation policy, and Polish authorities still denied basic rights to their people. ${ }^{103}$

While EVD provided temporary protection for persons fleeing dangerous situations, it was criticized for lacking eligibility criteria and for being linked to U.S. foreign policy objectives. ${ }^{104}$ Elizabeth Harris, in her work, argued that "EVD allowed the Attorney General and the State Department to take into account foreign policy issues rather than purely humanitarian concerns" and thus EVD granting was based on U.S. political interests. ${ }^{105}$ In later years, mass media reported protest calls from other groups like Salvadorans who complained about unfair treatment as refugees. The Chicago Tribune from 1987 raised the issue of unequal support based on the state of bilateral relations:

"Why Poland and why not El Salvador? The administration determined that EVD actions must be based not only on humanitarian but also on foreign policy and immigration impact criteria. Added to humanitarian factors, it justified the Polish EVD as centered on foreign policy requirements not the case with El Salvador. Because the lifting of economic sanctions has cleared the way for re-establishing normal bilateral relations with Poland, the foreign policy crisis that provided the underpinning for Polish extended voluntary departure has passed (...) At this time of national reckoning over the immigration failures of the past, basic fairness dictates that Poles not be treated differently from other nationality groups, painful though that may be."106

According to Deborah Anker, the number of admittances based on the Refugee Act of 1980 has been the subject of a great deal of publicity and criticism, most recently by major nongovernmental international human rights monitoring organizations. Amnesty International, for example, concluded in a 1990 report that

"Overwhelming evidence indicates violations of both the letter and spirit of the law in cases of asylum seekers coming to the United States in large numbers from countries with severe, widespread human rights abuses: El

\footnotetext{
103 "Lift Safe-haven Rules For Poles, Too," Chicago Tribune, May 19, 1987, http://articles.chicagotribune.com/1987-05-19/news/8702070117_1_martial-law-poles-immigrationenforcement.

104 Bill Frelick and Barbara Kohnen, "Filling the Gap: Temporary Protected Status," Journal of Refugee Studies (December 1995)," 341, accessed December 2, 2013, http://www.scribd.com/doc/ 61378238/Filling-the-Gap-Temporary-Protected-Status-Bill-Frelick-and-Barbara-Kohnen-Journal-ofRefugee-Studies-December-1995.

105 Elizabeth Harris, "Economic Refugees: Unproptected in the United States by Virtue of an Inaccurate Label," American University International Law Review 9, no. 1 (1993): 293.

106 "Lift Safe-haven Rules For Poles, Too."
} 
Salvador, Guatemala and Haiti." Amnesty cited statistics from the Immigration and Naturalization Service (INS) that, between June 1983 and September 1989, of 1,834 asylum applications filed by Haitian applicants, only 39 were granted. "In contrast, during the same period... the approval rate for asylum seekers from the U.S.S.R. was 72.6 percent, eastern European countries such as Romania 70.3 percent. (...)."107

It can be surmised that Reagan continued a postwar policy of admitting large numbers of refugees fleeing communist regimes as the refugee policy played an important role in the U.S. struggle against the Soviet Union. It can be seen from the table provided by the INS Statistical Yearbook that nine out of the top ten immigrant sending countries were governed by a communist-type regime. ${ }^{108}$

Table 2. Immigrants admitted as permanent residents under the Refugee Act, 1981-1990.

\begin{tabular}{lcc}
\hline \hline Country of Birth & 1981-90 Total & Regime Type Escaped From \\
\hline Vietnam & 324,453 & Communist \\
Laos & 142,964 & Communist \\
Cambodia & 114,064 & Communist \\
Cuba & 113,367 & Communist \\
Soviet Union & 72,306 & Communist \\
Iran & 46,773 & Anti-American \\
Poland & 33,889 & Communist \\
Romania & 29,798 & Communist \\
Afghanistan & 22,946 & Communist \\
Ethiopia & 18,542 & Communist
\end{tabular}

Source: INS Statistical Yearbook in: Daniel J. Tichenor, Dividing Lines: The Politics of Immigration Control in America (Princeton University Press, 2009), 263.

Furthermore, according to Tichenor's account the Republicans argued that the reason for admitting more refugees from Europe was due to the fact that most central

${ }^{107}$ Immigration and Naturalization Service, Asylum Cases Filed with INS District Directors Approved and Denied, by Select Nationalities. (Washington, DC: INS, October 1988-July 1989).

108 INS Statistical YearbookDaniel J. Tichenor, Dividing Lines: The Politics of Immigration Control in America (Princeton:Princeton University Press, 2009), 263. 
and south Americans including Haitians and Salvadorans left their homelands more for economic rather than political reasons. ${ }^{109}$

\section{WAKACJUSZE AND THE IMMIGRATION REFORM AND CONTROL ACT ( IRCA ) OF 1986}

Apart from the inflow of Polish refugees or political immigrants, when Polish passport policy became less rigorous, many Poles arrived to the U.S. as so-called Wakacjusze (vacationers, officially classified as temporary visitors for pleasure). Many of them violated the restrictions of their visas by working in the U.S. without permission and overstayed their six-month limitations. Poles often took advantage of their temporary stay in the U.S. in order to take up paid work and bring money back to Poland or not to return at all and begin a new, prosperous life. The term " wakacjusze “(Vacationers) was popularized by Zofia Mierzyński in her 1983 novel Wakacjuszka. ${ }^{10}$ In her novel, the author presented the adventures of a rural Polish woman who immigrated to Chicago to earn money for a new tractor.

Job opportunity and improved standards of living were the main objectives for most Wakacjusze or economic migrants. As she wrote, economic issues were even dominant among political refugees. These immigrants took up illegal employment; women mainly took housekeeping work in private homes and men kept up with seasonal jobs in small construction companies (often Polish firms). These employees were not registered, and therefore did not have insurance, and the employer did not pay taxes for them. Both sides, of course, were exposed to the control of the immigration service. Hence, many wakacjusze sought to obtain permanent residence. One must note that the access to precise statistics of Wakacjusze is extremely difficult. This is mainly due to large fluctuations in their number and lack of strict control by the immigration service. However, the average number of visitors oscillated from 24,000 annually in the 1970 's to over 40,000 in the 1980 's, to almost 50,000 in the 1990 's. Many of those vacationers worked without authorization and a significant number overstayed their visas. ${ }^{111}$ Mary Erdmans estimates that nearly 450,000 nonimmigrants in the 1980's arrived in the U.S., from which almost 80 percent came as temporary visitors for

\footnotetext{
${ }^{109}$ Ibid., 263-268.

${ }^{110}$ Zofia Mierzyńska, Wakacjuszka (Warszawa: Wydawnictwo Ex Libris, 2003).

${ }^{111}$ Waters, Ueda, and Marrow, The New Americans, 573.
} 
pleasure. ${ }^{112}$ In Erdmans' account, we can read that the director of the Polish Welfare Association in Chicago in 1988 estimated that approximately one-third of the wakacjusze had overstayed their visa limitations, so that the number of wakacjusze in the United States in any given year could have been far greater than the annual number of the admitted newcomers. Using this one-third estimate, by 1991 there were about a quarter of a million wakacjusze in the United States. ${ }^{113}$

With increasing apprehensions of aliens attempting to cross the southern border during the 1970's and 1980's and evidence of the considerable presence of unauthorized persons--particularly in California, Texas, Florida, New York and Illinois, states with considerable labor demands - a legislative response became necessary. Congress enacted immigration reform legislation which dealt with the problem of illegal immigration by granting legal status for unauthorized residents. In order to reduce this population the 1986 Immigration Reform Act provided an amnesty to more than 16,000 Poles and 2,000 of their dependents among others. Most of these amnesty recipients were officially admitted between 1989 and 1993, and that can partly explain the statistical surge in official immigration in the 1990's. ${ }^{114}$ The Immigration Reform and Control Act (IRCA) of 1986 introduced two programs to legalize illegal immigrants. Regular amnesty covered more than 1.7 million foreigners who were able to prove that they came to the U.S. before January 1, 1982 and had resided in the country continuously $^{115}$ :

"The law, signed by President Reagan on Nov. 6, offers the chance to obtain legal status if an immigrant who illegally entered the U.S. can prove he or she has resided here with few absences since Jan. 1, 1982. A second phase of the law, penalizing employers who knowingly hire illegal immigrants, begins taking effect in two stages on June 1."116

Another part of the act created civil and criminal penalties for U.S. employers who knowingly hired undocumented immigrants. IRCA obliged employers to verify the status of already employed workers; however, the established data verification system

\footnotetext{
112 Erdmans, Opposite Poles, 63.

113 Ibid., 63-65.

114 Waters, Ueda, and Marrow, The New Americans, 575.

115 Elliott Robert Barkan, Immigrants in American History: Arrival, Adaptation, and Integration (ABCCLIO, 2013), 1586.

116 Dianna Solis and Constanza Montana, "Immigration-Amnesty Begins Smoothly But With Much Anxiety for Immigrants,” Wall Street Journal, Eastern Edition, May 6, 1987.
} 
was voluntary and as a result did not bring about the intended outcomes, as most employers were satisfied with an independent assessment of the documents submitted by the candidates.

"Our people live like hunted game (...)You stay as close as possible to the family, don't socialize much, don't talk at work, hide behind someone else's Social Security card, don't get a driver's license."117

In Chicago's immigrant communities, the 1986 law created a buzz of excitement. Grazyna Zajaczkowska, 28, was a student with a master's degree in fine arts from communist Poland when she learned about the chance to fix her immigration status.

"Her student visa had expired, and Zajaczkowska and her husband, Pawel, faced being deported to their homeland. Back then, returning to Poland meant being cut off from family members who remained in Chicago, she said. "We were really desperate," Zajaczkowska said. "We had our little suitcases packed up just in case."

"Along with thousands of other people that winter, the Polish couple waited in long lines in the Chicago cold to hand in their applications and proof of residency. At first, they were denied. But they tried again and became U.S. citizens in the mid-1990s."118

\section{Difficulties of Polish immigrants}

When analyzing immigration policies of the admitting countries it would be false to say that the borders of those countries were totally open for all Poles who attempted to escape from poverty or various persecutions. According to Zolberg, there was an enormous wave of economic emigrants or the so-called 'economic refugees' seeking opportunities for themselves in rich post-industrial countries. ${ }^{119}$ Along with the newly adopted definition of refugee, there was a discussion of how to define persecution, since there was no universally accepted definition of "persecution." In practice, verification of Polish immigrants based on political refugee status required further clarification. The definition of a political refugee was problematic, since it could

\footnotetext{
117 Samuel G. Freedman, "A State of Limbo Rules the Live of Polish Aliens.," The New York Times, February 21, 1982, sec. N.Y. / Region, http://www.nytimes.com/1982/02/21/nyregion/a-state-of-limborules-the-lives-of-polish-aliens.html.

118 "Immigration Reform Likened to 1986 Amnesty," Chicago Tribune, accessed November 28, 2013, http://articles.chicagotribune.com/2013-02-03/news/ct-met-amnesty-immigration20130203_1_immigration-law-immigration-overhaul-problem-with-illegal-immigration. ${ }^{119}$ Aristide R. Zolberg and Peter M. Benda, Global Migrants, Global Refugees: Problems and Solutions (New York: Berghahn Books, 2001), 103.
} 
apply to someone who obtained political asylum or refugee status in the country of destination, or when he or she left his/her native country due to political persecution. This dual definition may have, however, caused a lot of problems. For instance, there may have been situations in which a person left the country due to economic reasons resulting from the political situation. ${ }^{120}$ Risk of persecution was an even looser concept that allowed for admission or rejection of the interpretation of the refugee.

It was argued, for instance, that restriction to move freely constituted a restriction of liberty; such occurred in all countries of the Soviet bloc, where the privilege of owning a passport or freedom of movement within the interior were limited. ${ }^{121}$ However, there was controversy with regards to proving the risk of being persecuted, the so-called "Burden of Proof." In the case of an emergency escape or natural disaster, a person may not have been able to produce sufficient evidence of risk to his/her freedom and persecution in the country of previous residence. In such cases, the Immigration Service (INS) was willing to treat oral testimonies as credible statements. ${ }^{122}$ Nevertheless, in the Polish case, for the INS it was often clear that the oppressive communist regime in Poland in the 1980s did not look like the one from the Stalinist era. Moreover, only a relatively small percentage of refugees could prove direct persecution. According to a New York Times article from 1982:

"The definition (of a refugee) appears to exclude most Polish aliens, Mr. Day said, because they came to the United States for economic gain. "What we hear about are food shortages, fuel shortages," he said, "not political reasons." But Polish aliens rarely extricate the shortages from the Communist government that presides over the economy." 123

In another New York Times article from 1985 we read an opinion in the reference to the increasing number of Polish refugee applicants from a consular worker at the U.S. embassy in Warsaw who said that many of personal testimonies were embellished:

\footnotetext{
${ }^{120}$ Harris, Economic Refugees: Unproptected in the United States by Virtue of an Inaccurate Label, 307.

121 Carolle Charles, "Political Refugees or Economic Immigrants?: A New 'Old Debate' Within the Haitian Immigrant Communities but with Contestations and Division," Journal of American Ethnic History 25, no. 2/3 (January 1, 2006): 190-208.

${ }^{122}$ Cisek, Polish Refugees and the Polish American Immigration and Relief Committee, 183.

${ }^{123}$ Freedman, "A State of Limbo Rules the Live of Polish Aliens," New York Times (February 21, 1981), http://www.nytimes.com/1982/02/21/nyregion/a-state-of-limbo-rules-the-lives-of-polish-aliens.html
} 
“(...) Once they get inside the building, everybody is a former Solidarity Union leader" 124

The situation of Polish immigrants was also raised in by the Wall Street Journal where an article included an explanation of U.S. immigration officials with regards to the increasing number of refugee denials due to insufficient motives:

“(...) many Poles, even if they have been persecuted in the past, don't have that fear today in relatively liberal Poland. The reason they are being turned down is essentially because they have left Poland only because they feel they have been denied a certain standard of living (...) Mr. Marciak adds, 'Our people are being rejected because the U.S. says they have no good reason from leaving Poland, says Mr. Marciak. '(...) My God, in one day 87 were interviewed and only seven were accepted",125

In a Polish Review-Nowy Dziennik (a Polish newspaper) article from March 1982 we can find a note about several formal disputes over the distinction between political and economic immigrants. According to the article, many western countries claimed that Poles could have not been considered political refugees, but candidates for economic emigrants. A representative of the High Commissioner (UNHCR) in Austria, Frederick Pijnacker (Dutch), expressed himself:

"No, decidedly, we cannot consider Poles as refugees. Nor do we have the resources to help them ... Poles come to Austria to get out into the world in search of jobs and better income. In Poland, nothing is imminent but the poverty." 126

A similar view was presented by the American consul in Vienna, who determined which candidates could emigrate to the U.S., saying, "We strictly need to stick to the definition of 'refugee' and the position of the Poles has to be weighed against that of those who are considered from a real disaster in Southeast Asia" ${ }^{127}$.

\footnotetext{
${ }^{124}$ Michael T. Kaufman, "Poles, With Plenty of Passports, Line Up for Visas," New York Times, July 22, 1985; http://search.proquest.com.www.libproxy.wvu. edu/hnpnewyorktimes/docview/111293401/abstract/1420EC7795C1BB8671C/99?accountid=2837.

${ }^{125}$ David Brand, "Poles Who Seek Asylum in the U.S. Languish in Austria: Washington Called Too Strict On Entry Requirements; Thousands at Two Camps Poles and Austrians Upset at U.S. On Policy Toward PolishRefugees, ”WallStreetJournal(September17,1981),sec.1, http://search.proquest.com.www.libproxy. wvu.edu/docview/134599305/abstract?accountid=2837.

126 "Austria Finds Polish Inflow a Burden,".The New York Times, January 10, 1982, http://www.nytimes.com/1982/01/10/world/austria-finds-polish-inflow-a-burden.html ${ }^{127}$ Ibid.
} 
More disputes on qualifying Poles as political immigrants took place in the eighties, as there was no consensus whether the point of reference should be the definition of a political refugee or simply "factors of political nature." The Polish Kultura magazine, printed in France, also drew attention to the differences in the treatment of Poles in different countries. In November 1982, the magazine published an interview with the U.S. government attorney for Refugees, Mr. Douglas, who criticized the Austrian policy toward refugees from Eastern Europe and warned that the U.S. would not grant immigrant visas to economic refugees. The Minister of Internal Affairs of Austria, Erwin Lano, in his response urged that the United States depart from distinguishing Polish refugees as economic or political, since it was difficult to apply such criteria to refugees from Eastern Europe after the imposition of martial law on December 13, 1981. ${ }^{128}$ In PAIRC's account, an argument was made that the financial crisis in the U.S. had an impact on policy in relation to the problem of refugees and was primarily concerned with reducing the huge number of refugees:

"When four years ago, the number of refugees reached 200,000, in the last year 1981/1982 allowed only about 90,000, and this year is said to be about 55 thousand, out of which about 15,000 from Eastern Europe, including Russia and Romania. For Polish immigrants we expect 7000 visas, but the majority of those visas will go to Solidarity members - who are registered in our office in Germany [...]".

\section{CONCLUSION}

This section showed the impact of the main U.S. immigration policies on Polish immigration to the U.S. during the last decade of communism in Poland. I demonstrated that the Polish immigration determinants were based on the Polish internal situation, arguing that in the last decade of communism following the imposition of martial law, there was a huge drop in international mobility, which nonetheless created a high readiness to migrate or willingness to remain in the visiting country. I argued that apart from the internal determinants accelerating Polish emigration to the U.S., the inflow of Poles to America was also influenced by the U.S. immigration policies such as Refugee Act of 1980 and IRCA Act of 1986. Based on retrieved data it can be said that the aforementioned policies did have a substantial impact on Polish immigrants. The

${ }^{128}$ Cisek, Polish Refugees and the Polish American Immigration and Relief Committee, 182. 
policies gave Poles more options to enter or remain in the United States. It was also presented that Poles remained the most numerous group out of all eastern and central European countries. Nevertheless, that did not mean that Polish immigrants did not encounter difficulties when applying either for refugee status or legalizing their stay while in the U.S.

I argued that although the definition of refugee was eliminated and replaced with the non-discriminatory, non-ideological United Nations definition, it still was a source of confusion. I brought up the problematic issue of refugee verification with regards to Polish refugee applicants who often found it difficult to prove the aforementioned "well-grounded fear of persecution." Nevertheless, based on primary public materials I also discovered that the impact of Refugee Act 1980 and IRCA 1986 placed Poles ahead of many other refugee-producing countries. This indicated an instrumentalist attitude where over 90 percent of the refugee admissions from abroad came from communist or communist-dominated countries. According to Deborah Anker, "Congress has done very little to influence the determination of groups which are of 'special humanitarian concern' to the United States. Central Americans as well as Haitians or Salvadorans, for example, have been ineligible to apply for refugee status outside the United States. ${ }^{129}$,

129 Deborah, Anker, "The Development of U.S. Refugee Legislation." (New York, The Center for Migration Studies of New York,Inc.) 159-166. Accessed January 04 from http://www.jstor.org/discover $/ 10.2307 / 23141064$ ?uid=3738840\&uid=2\&uid=4\&sid=21103316126641. 


\section{POLISH IMMigRATION TO THE U.S. SINCE 1990}

This chapter will attempt to discuss Polish immigration to the U.S. after the collapse of communism and outline the impact of new U.S. immigration policies on Polish immigrant inflow in the first decade of free and democratic Poland. I will demonstrate that the character of Polish immigration in the U.S. evolved and ceased to have a political and humanitarian character. I will show that the U.S. in the 1990's established certain immigration policies that affected the new Polish wave especially in the first years of the decade, when the U.S. border became more hermetic. Going further, I will briefly outline the question of the visa waiver program as an aspect of Polish-American relations and decline of Polish inflow into the U.S.

\section{NEW DECADE, NEW REGULATIONS.}

The new decade brought a number of changes that resulted from the political transformation in Poland. After 1989, despite a number of problems and the remaining presence of Soviet troops, there was no doubt that Poland was becoming a sovereign state. The dismantling of the communist regime and the new democratic image of Poland made Poles lose their 'burden of proof' in the eyes of many refugee-receiving countries. As Mary Erdmans notes, those 'Polish refugees admitted in the early 1990's represented "American processing backlogs." 130 Following Fix and Passel's three distinct parts of U.S. immigration policy: (1) legal immigration, (2) humanitarian admissions, and (3) illegal immigration, ${ }^{131}$ one can say that Polish immigrants in the eyes of the U.S. Department of State were no longer eligible to qualify as refugee applicants:

"In 1991 Poland completed the transition from a refugee generating country to a refugee receiving one. In light of continuing democratic reforms in Poland, Western countries found virtually no Pole eligible for refugee status in 1991. Germany, where most Polish asylum seekers applied, denied all but a handful of the 3,448 applications - the ones approved consisted of family members joining a previously adjudicated

${ }^{130}$ Erdmans, Opposite Poles, 65.

${ }^{131}$ Fix and Passel, "Immigration and Immigrants. Setting the Record Straight,"12. 
refugee. Moreover, significantly fewer Poles applied, compared to 9,155 in 1990 and 26,092 in 1989"132.

Table 3. Polish Refugees and Asylum Applicants granted permanent resident status in the United States 1961-1992

\begin{tabular}{lrr}
\hline Years & Number & Percent \\
\hline $1961-70$ & 3,197 & 6.6 \\
$1971-80$ & 5,882 & 12.1 \\
$1981-90$ & 33,889 & 69.6 \\
$1991-92$ & 5,717 & 11.7 \\
Totals & 48,685 & 100.0 \\
\hline
\end{tabular}

Source: Statistical Yearbook of the Immigration and Naturalization Service, 1990 (table 34),1993(table 33), Washington, D.C.:GPO.

According to the Statistical Yearbooks of the Immigration and Naturalization Service it can be seen that the number of Polish refugees and asylum seekers who were granted permanent resident status dropped from 33,889 to 5,717 in the first two years after the collapse of communism in Poland. Moreover, in 1994 the number of Polish refugees admitted to the U.S. amounted to only 240, in 1997 that number dropped to 101, and in 1998 only 44 Poles were admitted under the refugee act $1980 .{ }^{133}$ According to the New York Times from 1989, the U.S. government already portended a refusal of admissions of Poles and Hungarians, arguing that most of them no longer had any reason to fear persecution in their homelands:

"Nancy Bearg Dyke of the National Security Council staff told representatives of the ethnic organizations, that under the new policy 'we will not consider Poles or Hungarians for the Refugee resettlement program unless they have relatives in the U.S., face immediate threats to their lives or have exceptionally strong ties to this (the U.S.) country."134

${ }^{132}$ Cisek, Polish Refugees and the Polish American Immigration and Relief Committee.

133 United States. Immigration and Naturalization Service, Statistical Yearbook of the Immigration and Naturalization Service [microform] (Washington, D.C.: U.S. G.P.O., 1994), http://archive.org/details/statisticalyearb1994unit; United States. Immigration and Naturalization Service, Statistical Yearbook of the Immigration and Naturalization Service [microform] (Washington, D.C. : The Service : U.S. G.P.O., 1997), http://archive.org/details/statisticalyearb1997unit.

${ }^{134}$ Robert Pears, "Number of Poles and Hungarians Admitted as Refugees Will Be Cut: U.S. Planning to Curtail the Number of Poles and Hungarians Admitted as Refugees," New York Times (November 22, 1989), A15. 
The same newspaper said that the U.S. refused refugee status for at least 19,000-20,000 Poles and Hungarians who had already filed applications at U.S. embassies and consulates in western countries. Only about 1,000 had a real chance for an interview invitation in order to receive refugee status. ${ }^{135}$ Gerald Coyle, Acting Chief of Staff of the Immigration and Naturalization Service said:

"Conditions in Poland and Hungary have markedly improved, thus they are unlikely to have very substantial claims to U.S. refugee status." 136

Nevertheless, in 1989 there was still disagreement coming from Polish applicants or Polish-American representatives stating that police, militia and security forces still harassed people who participated in anti-Communist political activities. Myra Kenard, an executive director of the Polish American Congress, stated that

'It will take years for the system to change. People in some provinces of Poland still feel the brunt of discrimination at the hands of communist party members. ${ }^{137}$

The still unstable situation continued to push Poles to emigrate. This can be seen in a number of Poles applying for a legal permit entry which did not lessen, quite the contrary, it rose shortly after the U.S. introduced a new immigration law in 1990. It must be also noted that the Polish cross-border mobility, especially after 1989, changed its character. People usually went abroad, having return in mind, which gave their journeys a sense of personal travel. ${ }^{138}$

\section{U.S. IMMIGRATION ACT OF 1990}

The U.S. Immigration Act of 1990 provided the most comprehensive change in legal immigration since 1965 as it established a 'flexible' worldwide cap on familybased, employment-based and diversity immigrant visas. The Immigration Act of 1990, which was in fact another amendment to the McCarran-Walter Act, increased the annual quota limit to 700,000 in 1992-1994 and to 675,000 in subsequent years, out of which

\footnotetext{
135 Ibid., A15.

136 Ibid., A15.

137 "Clamor in the East; Number of Poles and Hungarians Admitted as Refugees Will Be Cut - Page 2,"New York Times, (Novermber 22, 1989) accessed January 6,2014,http://www.nytimes.com/1989/11/22/world/clamor-east-number-poles-hungarians admittedrefugees-will-be-cut.html?pagewanted=2.

138 Ewa Jażwińska-Motylska and Marek Okólski, Ludzie na huśtawce: migracje między peryferiami Polski i Zachodu (Warszawa, Wydawn. Naukowe Scholar, 2001).
} 
the majority went to family-sponsored visas, 480,000; 140,000 was reserved for employment-based visas and 55,000 for the diversity visas based on criteria of ethnic diversification (40,000 until 1994). In total, the law increased immigration to the U.S. by 35 percent. $^{139}$

The Act of 1990 played a tremendous role for Polish immigrants as the new legislation reopened the door to those immigrants who were traditionally the main category of immigrants in the past but had been "foreclosed from immigrating due to the variages of the law of 1965." 140 Poles, as a result of 1965 amendments, similar to Irish or Italians, were shut out of the system due to the shift toward the Asians and Latinos. A list of "adversely affected countries" was generated with such a country defined as any country that did not use more than 25 percent of its 20,000 annual allotment of visas. People from those countries were allowed to apply on a preferential basis. Anna Law gives three reasons that supported the higher visa allotment to those adversely affected countries, including Poland. ${ }^{141}$

"First, our Nation must reintroduce into the immigrant stream those countries that have been determined to be adversely affected by the act of 1965 and face the same barriers with the passage of the 1986 reform bill." Second, the NP-5 ${ }^{142}$ program held out the possibility of legal immigration for those who would normally come illegally (or who was presently illegally residing in the United States). Third, NP-5 would allow for natives of the adversely affected thirty-six countries to compete in a more "equitable" manner with other nationalities."143

It should be recalle that although the Act of 1965 was admirable in ending discrimination against immigrants based on national origins, the southern and eastern Europeans who were expected to benefit from the 1965 law were effectively excluded from the immigrant pool on an equal basis with residents of northern and western Europe.

\footnotetext{
${ }^{139}$ Richard W. Day, "The Immigration Act of 1990 and the New Congress," In Defense of the Alien 18 (January 1, 1995), 69-71.

${ }^{140}$ William V. Jr Roebuck, "Move to Employment-Based Immigration in the Immigration Act of 1990: Towards a New Definition of Immigrant, The, North Carolina Journal of International Law and Commercial Regulation 16 (1991), 523.

141 Anna O. Law, "The Diversity Visa Lottery: A Cycle of Unintended Consequences in United States Immigration Policy," Journal of American Ethnic History 21, no. 4 (July 1, 2002): 16.

${ }^{142}$ NP-5 sought to amend section 314 of the Immigration and Nationality Act of 1990.

${ }^{143}$ Law, "The Diversity Visa Lottery,"'12.
} 
As a result of the Act of 1990, Polish immigrants readily took advantage of the Act, making Polish immigration one of the largest legal, migratory currents from Europe to the U.S. As Duane Gory states, the 25,504 Polish immigrants who came to America in FY 1992 constituted a 2.6 percent of all FY 1992 admissions to the United States. This made Poland the ninth largest country of departure for immigrants to America in FY $1992^{144}$.

Table 4. Polish Immigrants Admitted To The United States

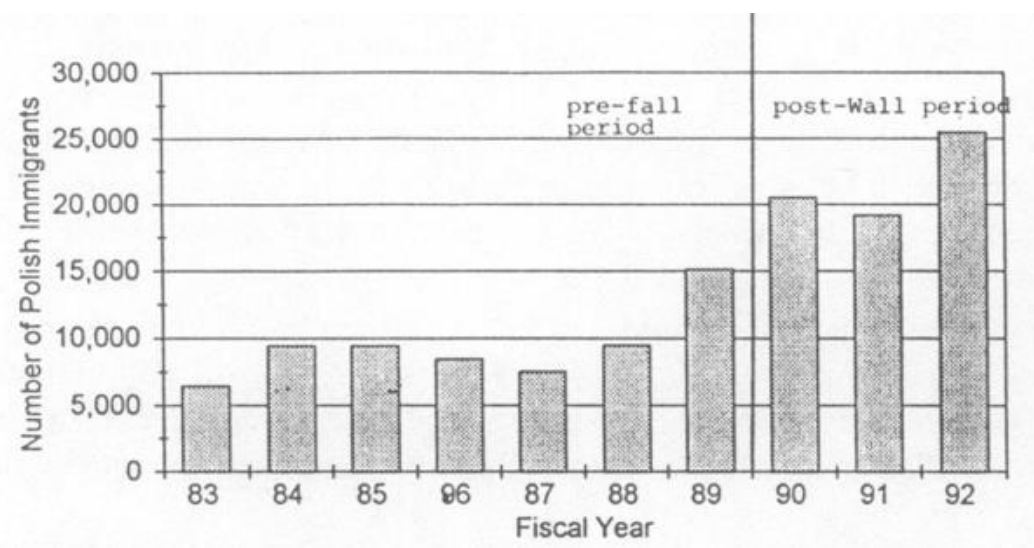

Source: Duane Gory, "Polish Immigration To America: Before and after the fall of the Berlin Wall" The Polish Review, 40, 1), 76.

One of the factors that influenced the Polish inflow was the erection of the Diversity Transition Program, the so-called "Green Card Lottery" which constituted a part of the Immigration Act of 1990.

\section{ACT OF 1990, DV Visa LotTery AND THE POLISH CASE}

As part of the Immigration Act of 1990, the U.S. government tended to encourage legal immigration from countries other than the major immigrant-sending countries to the United States. As aforementioned, the allocation of immigrant visas was heavily focused on aliens with close family members in the United States and, to a lesser extent, toward aliens who met the particular employment needs. The introduction of the so-called Green Card Lottery added new value to the U.S. Immigration Policy as 
it was neither a family nor employment-based policy, but was classified under the independent immigration track. There were two diversity programs, the first had a transitional character and ran in fiscal years 1991-1994. It provided 40,000 visas for the immigrants in each fiscal year. It must be admitted that the DV Visa lottery was the first one in the U.S. history that introduced a system where the computer would randomly draw the numbers from the total applications received. The only requirement for each immigrant was to hold a high school degree or at least 2 years of work experience $^{145}$.

"By a vote of 231 to 192 the House approved legislation that would increase the number of legal immigrants to 775,000 a year from the current speed. (...) the bill also singles out specific immigrant groups for special treatment. Countries like Italy, Poland and Argentina would gain thousands of new visas annually under the provision that grants preferential treatment to 55,000 applicants a year from countries that have accounted for less than 50,000 immigrants in the previous five years." 146

As Poles were adversely affected by the 1965 immigration provisions, they particularly benefited from the diversity visas. Between 1992-1997, 53,000 Poles were admitted under this program. ${ }^{147}$ It is worth noting that the majority of those 55,000 diversity immigrant slots (a year) went to European immigrants where Poles remained the biggest number of recipients. ${ }^{148}$ According to Mary Erdmans: "Only between 1990 and 1993, 93,086 Poles were admitted under numerical limitations, whilst in the three previous decades all together the number was 201,606."149.

In short, those whose relatives were U.S. citizens, U.S. residents or represented professional and highly sought skills could count on legal immigration to the U.S. Those, however, who craved to work as immigrant-workers and did not qualify under family-based or professional skills program could still work legally only if they won an immigrant visa in the DV lottery.

\footnotetext{
${ }^{145}$ Law, “The Diversity Visa Lottery,” Journal of American Ethnic History 21, no. 4 (July 1, 2002), 18.

146 Nathaniel C. Nash, "Immigration Bill Approved in House: New Provisions Seek to Allow 775,000 Foreigners Yearly -- New Talent Is Goal," New York Times, October 4, 1990.

${ }^{147}$ Waters, Ueda, and Marrow, The New Americans, 573.

${ }^{148}$ Erdmans, Opposite Poles, 65.

${ }^{149}$ Ibid.,67.
} 
As Mary Erdmans estimates, one-third of Polish visitors on tourist visas prolonged their stay, and as a result in 1991, there were about 250,000 of "wakacjusze" from Poland in the United States. The number of people traveling to the U.S. for business purposes increased after 1989. In total, the vast majority of immigrants between 1960 and 1993 (approximately one million) came to the U.S. as tourists, and a smaller group as legal immigrants, of which more than three quarters benefited from family reunification clause and the professional employment clause. According to Krystyna Iglicka's reaseach, current holiday work programs Work and Travel were partly introduced in order to decrease the number of illegal immigrants and illegal temporary/holiday employment. ${ }^{150}$ According to the Immigration and Naturalization Service statistics from 1996 Poles were still among the top ten national groups that remained in the U.S. illegally. ${ }^{151}$

The number rose in 1989 and steadily increased until 1992 About forty-six thousand temporary visitors for pleasure came between 1990 and 1993 compared to an average of thirty-five thousand annually in the 1980 's. ${ }^{152}$. In the early 1990 s, the United States government continued to grant Polish citizens the multiple-entry, usually ten-year visas for six-month visits. Visitors seeking illicit income in America notoriously overstayed the duration of their visas. As Morokvasic pointed out at the beginning of 1990s:

"The most characteristic of the post 1989 migrations, and the least known in the West, are the circulatory migrations or commuting of tourists; these involve various types of income-generating activities, mostly trading. They existed on a limited scale before the rise of the iron curtain. These tourists stay for periods ranging from several hours to several months." 153

In response to the increasing number of illegal immigrants, the Clinton administration implemented the Illegal Immigration Reform and Responsibility Act in

\footnotetext{
${ }^{150}$ Krystyna Iglicka, Badanie Nad Migracjami Zarobkowymi z Polski Po 1 Maja 2004 Roku Do USA, Biuletyn Migracyjny - Dodatek 15 (2007).

${ }^{151}$ United States. Immigration and Naturalization Service, Statistical Yearbook of the Immigration and NaturalizationService[microform](Washington,D.C. :U.S.G.P.O.,1997), http://archive.org/details/statisticalyearb1997unit.

152 Erdmans, Opposite Poles, 65.

153 Mirjana Morokvasic, "Transnational Mobility and Gender: a View from Post-wall Europe," in Crossing Borders and Shifting Boundaries, ed. Mirjana Morokvasic, Umut Erel, and Kyoko Shinozaki,in Technik Und Kultur « 10 (VS Verlag für Sozialwissenschaften, 2003), 101-133, http://link.springer.com/chapter/10.1007/978-3-663-09529-3_6.
} 
1996 that tightened penalties for visa violations by forbidding such migrants another entry to the United States for a ten- year period. The Act of 1996 also imposed criminal penalties for "racketeering, alien smuggling and the use or creation of fraudulent immigration-related documents and increasing interior enforcement by agencies charged with monitoring visa applications and visa abusers."154 Eligibility verification of employees as well as employers was also incorporated into the act, which included sanctions for those who failed to comply with the regulations and restrictions on unfair immigration. As Morawska notes:

“(...) the undocumented Polish visitors responded to this new legal situation with an immediate increase of back-and-forth travels within the legally prescribed time. They avoided the dangers of undocumented status (but still break the law by illicit employment) by returning to Poland every six months, remaining there for a few weeks, and coming back to the United States, often to resume the same jobs in the informal sector." 155

Moreover, the IIRIRA Act of 1996 increased the income level required of persons serving as guarantors for family members. Henceforth, the level would be set at least $120 \%$ of the poverty threshold. The new regulation was designed to reduce the number of sponsored immigrants. ${ }^{156}$

Table 5 .

Foreign Visitors for Pleasure Admitted, Poland being their Country of Last Residence ${ }^{157}$

\begin{tabular}{|c|c|c|c|c|c|c|c|c|c|c|}
\hline Years & 1986 & 1987 & 1988 & 1989 & 1990 & 1991 & 1992 & 1993 & 1994 & 1995 \\
\hline $\begin{array}{c}\text { Poland } \\
\text { (in thousands) }\end{array}$ & 8 & 4 & 3 & 2 & 5 & 4 & 8 & 2 & 3 & 6 \\
\hline
\end{tabular}

154 "Illegal Immigration Reform and Immigration Responsibility Act," accessed January 6, 2014, http://www.law.cornell.edu/wex/illegal_immigration_reform_and_immigration_responsibility_act.

${ }^{155}$ Ewa Morawska, "Structuring Migration: The Case of Polish Income-Seeking Travelers to the West," Theory and Society 30, no. 1 (February 1, 2001): 47-80.

156 OECD, Trends in International Migration 1999: Continuous Reporting System on Migration (OECD Publishing, 1999), 223.

${ }^{157}$ Statistical Abstract of the United States (Washington, D.C: U.S. Government Printing Office, 1991). 


\section{VWP - the Visa Waiver Program and the Polish Case}

One of the problems in Polish - American relations has been the issue of Polish membership in the VWP (Visa Waiver Program). In 1986, the U.S. congress enacted the VWP to enable nationals of certain countries to travel to the U.S. for tourism or business purposes and stay up to 90 days without obtaining a visa. By 1989, the Attorney General and the Secretary of State designated eight countries to participate in the program. In 2000, the Visa Waiver Program commenced operating on a permanent basis. Each country had to meet the same basic criteria, namely a similar non-visa requirement for the U.S. citizens and a low percentage of rejected nonimmigrant visa applications (maximum of $3 \%$ in a fiscal year).

In 15 April 1991, Poles lifted the visa requirement for U.S. citizens to attract American tourists and investors and to facilitate travel for those Poles who were living in the USA. Nevertheless, Poles did not qualify for the VWP as the program originally concerned only a few U.S. allies and the refusal percentage for the Polish visa applicants far exceeded the required $3 \%$.

The first diplomatic mention about the visa waiver program with regard to Poles appeared during the visit of President Aleksander Kwasniewski to the U.S. in July 1996, but by the end of the 1990s the visa waiver issue had become peripheral to U.S.-Polish relations. Even in 2001, in response to a parliamentary interpellation of the Ministry of Foreign Affairs on the state and prospects of development of Polish-American relations, the issue of visas did not come up. The issue of VWP reappeared only during the visit of President George W. Bush in Warsaw in June 2001, but no action was taken. The problem of visas was officially moved as a negotiating issue during President Kwasniewski's visits to the U.S. in July 2002 and January 2003, when during the latter it was agreed that the matter would be the subject of joint consultations. However, these consultations resulted in a lack of significant findings, as Americans could not achieve the main Polish postulates (visa-free travel or abolition of visa fees) without changing the legislation. The promise that Poland would join the countries covered by the visa 
waiver program was regularly repeated by successive U.S. presidents on the occasion of the American election campaigns and bilateral visits of country leaders. ${ }^{158}$

Furthermore, a recent study conducted by the Pew Hispanic Center shows that U.S. immigration policy after September 11, 2001 brought about a decline of legal immigration to the U.S. Meanwhile, in response to the unrelenting demand for labor in the U.S., it led to increased illegal migration mainly from South America and Asia. ${ }^{159}$ Nevertheless, in the face of economic crisis and geopolitical changes, i.e. the depreciation of the dollar against the Polish zloty and EU accession of Poland, the attractiveness of the U.S. for Poles fell drastically.

${ }^{158}$ Currently VWP covers 36 countries: Andorra, Australia, Austria, Belgium, Brunei, Denmark, Estonia, Finland, France, Greece, Spain, Netherlands, Ireland, Iceland, Japan, South Korea, Liechtenstein, Lithuania, Luxembourg, Latvia, Malta, Monaco, Germany, Norway, New Zealand, Portugal, Czech Republic, San Marino, Singapore, Slovakia, Slovenia, Spain, Switzerland, Sweden, Hungary, Great Britain and Italy.

${ }^{159}$ Krystyna Iglicka, "Immigration Policies and Security," Centrum Studiów Migracyjnych (Warszawa, 2006), 11. 


\section{CONCLUSION}

The phenomenon of U.S. immigration underwent tremendous changes since the U.S. was founded. It can be surmised that the immigration process in America has reached unprecedented levels as the result of a combination of factors, inter alia, the new immigration policies, which paved the way for significant growth in immigration. Nevertheless, as it was shown the system has been constantly shaped by the accompanying events-from foreign wars and national security concerns to the financial crisis, either opening or closing the door to the new immigrants.

This study set out to analyze a number of major aspects of U.S. immigration policy towards Polish immigration to the U.S. during the two decades of 1980's and 1990's. The thesis proved that U.S. immigration policy during the period attempted to respond to international issues and humanitarian concerns with three major changes in immigration laws in 1980, 1986, and 1990, thanks to which the U.S. received a significant number of immigrants and refugees. Moreover, in analyzing the evolutionary process of U.S. immigration policy, it appears that the U.S. immigration laws of the 1980's and 1990's had a number of fairly positive outcomes with regards to Polish immigration. This is because all of the aforementioned acts of the 1980's and 1990's attempted to sort out the issues in which Polish immigrants took a significant part.

The thesis showed that Cold War politics created an important constituency for an immigrant policy that could be seen in some aspects as no justifiable with regards to other non-communist nations. In spite of the officially present open door policy for refugees by the U.S, the White House continued the afore-oriented anti-communist discourse and often favored immigrants from the communist-dominated countries over the immigrants from Central and Latin America. Moreover, based on the retrieved data it can be presumed that the Reagan administration inscribed Polish immigrants into America's cold war rhetoric. Poland was to take a significant part in stabilizing the region of Eastern European countries. The fact that Poles were statistically the largest immigrant group out of all Eastern Europe countries or that they received the number of exclusive benefits such as EVD could prove that argument. 
Nevertheless, while analyzing the immigration process of Poles during that period, the study also pointed out the complex character of new laws with regards to refugees. The work presented the complicated nature of refugee verification, pointing out the blurred distinction between political and economic immigrants as well as the difficulties of proving the occurrence of risks to refugees, the so-called "Burden of Proof". It has been shown that the concept of the individual, often subjective opinion of immigration officers caused the rejection of many Polish applications and led to dissatisfaction among Polish applicants. On the other hand, it seems that the vast majority of Poles who immigrated to the U.S. often hid their real economic motives and chose to immigrate under the tourist visa as vacationers. The results of this study indicate that the two immigration decades analyzed had different departure characteristics. Moreover, U.S. immigration policy took different approaches toward Polish immigrants before and after the collapse of the Berlin Wall.

Nevertheless, the evidence from this study shows that although both immigration periods were controlled by different immigration policies, the most numerous immigrant group that is difficult to estimate were the so called 'vacationers' who immigrated on tourist visas, and illegally prolonged their stay. This group of immigrants is currently subject to statistical limitations for the study of Polish immigration to the U.S. Moreover, several other limitations to this study need to be acknowledged. Despite the existing literature on emigration of Poles to the United States in the 1980s, monographic studies or chapters on American immigration policy with regards to Poles during that period barely exist. Moreover, there are a number of publications whose content must be analyzed with caution. This is due to the fact that many of them were published for propaganda purposes. Thus, it seems to me that there is a need to focus on the new historiographical perspectives based on fresh data and statistics. The topic, with its great potential, provides more opportunities to understand the complex layers of interactions between the U.S and Poland. 


\section{BIBLIOGRAPHY}

ANKER, DEBORAH. “The Development of U.S. Refugee Legislation.” In Defense of the Alien 6 (January 1, 1983): 159-66.

. "U.S. Immigration and Asylum Policy: A Brief Historical Perspective." In Defense of the Alien 13 (January 1, 1990): 74-85.

“Austria Finds Polish Inflow a Burden.” New York Times. January 10, 1982. http://search.proquest.com.www.libproxy.wvu.edu/hnpnewyorktimes/docview/1 22128207/abstract/14219B307042430B287/5? accountid=2837.

Barkan, Elliott Robert. Immigrants in American History: Arrival, Adaptation, and Integration. ABC-CLIO, 2013.

Between Two Islands. Accessed November 26, 2013. http://www.ucpress.edu/book.php?isbn=9780520071506.

Bierzanek, Remigiusz, and Janusz Symonides. Public International Law. LexisNexis. Warszawa, 2002.

Briggs, Vernon. "Immigration and the U.S. Labor Market: Public Policy Gone Awry." CAHRS Working Paper Series, October 30, 1992. http://digitalcommons.ilr.cornell.edu/cahrswp/328.

Buenker, John D. Multiculturalism in the United States: a Comparative Guide to Acculturation and Ethnicity [...] [...]. Westport, Conn. [u.a.: Greenwood Press, 2005.

Bukowczyk, John J. Polish Americans and Their History: Community, Culture, and Politics. University of Pittsburgh Pre, 2006.

Cannato, Vincent J. "Our Evolving Immigration Policy." National Affairs 13 (Fall 2012): 112-28.

Charles, Carolle. "Political Refugees or Economic Immigrants?: A New 'Old Debate' Within the Haitian Immigrant Communities but with Contestations and Division." Journal of American Ethnic History 25, no. 2/3 (January 1, 2006): 190-208. doi:10.2307/27501695.

Cisek, Janusz. Polish Refugees and the Polish American Immigration and Relief Committee. Jefferson, N.C.: McFarland, 2006.

"Clamor in the East; Number of Poles and Hungarians Admitted as Refugees Will Be Cut - Page 2." New York Times. Accessed January 6, 2014.

http://www.nytimes.com/1989/11/22/world/clamor-east-number-poleshungarians-admitted-refugees-will-be-cut.html?pagewanted=2.

Coleman, Geraldine Balut. "Educating Polish Immigrants Chicago Style: 1980-2002.” Polish American Studies 61, no. 1 (April 1, 2004): 27-38.

Crawford, Beverly. Economic Vulnerability in International Relations: East- West Trade, Investment, and Finance. Columbia University Press, 2013.

Crizlap. "US Immigration Laws.” Docstoc.com. Accessed January 10, 2014. http://www.docstoc.com/docs/2310082/US-Immigration-Laws.

DAY, RICHARD W. "The Immigration Act of 1990 and the New Congress." In Defense of the Alien 18 (January 1, 1995): 69-71.

"Definition of Terms." Accessed January 4, 2014. https://www.dhs.gov/definitionterms\#8.

DeLaet, Debra L. U.S. Immigration Policy in an Age of Rights. Greenwood Publishing Group, 2000.

Drake, Bruce. "Unauthorized Immigrants: How Pew Research Counts Them and What We Know About Them." Pew Research Center, January 4, 2014. 
http://www.pewresearch.org/2013/04/17/unauthorized-immigrants-how-pewresearch-counts-them-and-what-we-know-about-them/.

Erdmans, Mary Patrice. Opposite Poles: Immigrants and Ethnics in Polish Chicago, 1976-1990. Penn State Press, 1998.

"Filling the Gap: Temporary Protected Status, Bill Frelick and Barbara Kohnen, Journal of Refugee Studies, December 1995.” Scribd. Accessed December 2, 2013. http://www.scribd.com/doc/61378238/Filling-the-Gap-Temporary-ProtectedStatus-Bill-Frelick-and-Barbara-Kohnen-Journal-of-Refugee-Studies-December1995.

Fix, Michael, and Jeffrey Passel. "Immigration and Immigrants. Setting the Record Straight." The Urban Institute, Washington, D.C., 1994.

Freedman, Samuel G. "A State of Limbo Rules the Live of Polish Aliens." The New York Times, February 21, 1982, sec. N.Y. / Region. http://www.nytimes.com/1982/02/21/nyregion/a-state-of-limbo-rules-the-livesof-polish-aliens.html.

Goldin, Claudia, and Gary D. Libecap. The Regulated Economy: A Historical Approach to Political Economy. University of Chicago Press, 2008.

Haines, David W. Refugees in America in the 1990s: A Reference Handbook. Greenwood Publishing Group, 1996.

Hammar, Tomas. European Immigration Policy: A Comparative Study. Cambridge University Press, 1985.

Harris, Elizabeth. "Economic Refugees: Unproptected in the United States by Virtue of an Inaccurate Label." American University International Law Review 9, no. 1 (1993).

HELTON, ARTHUR C. "Political Asylum Under the 1980 Refugee Act: An Unfulfilled Promise." In Defense of the Alien 6 (January 1, 1983): 201-6.

Iglicka, Krystyna. "Badanie Nad Migracjami Zarobkowymi z Polski Po 1 Maja 2004 Roku Do USA.” Biuletyn Migracyjny - Dodatek 15, 2007.

"Illegal Immigration Reform and Immigration Responsibility Act." Accessed January 6, 2014.

http://www.law.cornell.edu/wex/illegal_immigration_reform_and_immigration_ responsibility_act.

"Immigration Reform Likened to 1986 Amnesty." Chicago Tribune. Accessed November 28, 2013. http://articles.chicagotribune.com/2013-02-03/news/ct-metamnesty-immigration-20130203_1_immigration-law-immigration-overhaulproblem-with-illegal-immigration.

Jasinska, Magdalena. "Migration as an Issue in Contemporary Political Theory and Policy Analysis - the Potential Unused." Studia Migracyjne-Przeglad Polonijny, 2012.

Jażwińska-Motylska, Ewa, and Marek Okólski. Ludzie na huśtawce: migracje między peryferiami Polski i Zachodu. Wydawn. Naukowe Scholar, 2001.

JOURNAL, DAVID BRAND Staff Reporter of THE WALL STREET. "Poles Who Seek Asylum in the U.S. Languish in Austria: Washington Called Too Strict On Entry Requirements; Thousands at Two Camps Poles and Austrians Upset at U.S. On Policy Toward Polish Refugees." Wall Street Journal (1923 - Current File). September 17, 1981, sec. 1.

http://search.proquest.com.www.libproxy.wvu.edu/docview/134599305/abstract ?accountid=2837.

Kaczmarczyk, Paweł. Migracje zarobkowe Polaków w dobie przemian. Wydawnictwa Uniwersytetu Warszawskiego, 2005. 
Korcelli, Piotr. "International Migrations in Europe: Polish Perspectives for the 1990s." International Migration Review 26, no. 2 (July 1, 1992): 292-304. doi:10.2307/2547058.

Krywut-Albanska, Malgorzata. "Przyczyny i Okoliczności Emigracji z Polski w Latach 1980. Na Przykładzie Emigracji Do Kanady." Centre of Migration Research, 2011.

Kurzban, Ira J, and American Immigration Law Foundation. Kurzban's Immigration Law Sourcebook: a Comprehensive Outline and Reference Tool. Washington, DC: American Immigration Law Foundation, 2002.

Law, Anna O. "The Diversity Visa Lottery: A Cycle of Unintended Consequences in United States Immigration Policy." Journal of American Ethnic History 21, no. 4 (July 1, 2002): 3-29.

"Lift Safe-haven Rules For Poles, Too." Chicago Tribune, May 19, 1987. http://articles.chicagotribune.com/1987-05-19/news/8702070117_1_martiallaw-poles-immigration-enforcement.

Loescher, Gil, and John A. Scanlan. Calculated Kindness. Free Press, 1998.

Mangalam, J. J., and Cornelia Morgan. Human Migration: a Guide to Migration Literature in English, 1955-1962. University of Kentucky Press, 1968.

Marody, Mirosława. Co Nam Zostało z Tych Lat... Spoleczeństwo Polskie u Progu Zmiany Systemowej. London: Aneks, 1991.

Mierzyńska, Zofia. Wakacjuszka. Wydawnictwo Ex Libris, 2003.

Misiak, Władysław. Nowa Emigracja $i$ Wyjazdy Zarobkowe Za Granice. Wrocław: Polskie Towarzystwo Socjologiczne, 1991.

Morawska, Ewa. "Structuring Migration: The Case of Polish Income-Seeking Travelers to the West." Theory and Society 30, no. 1 (February 1, 2001): 47-80.

Morokvasic, Mirjana. "Transnational Mobility and Gender: a View from Post-wall Europe." In Crossing Borders and Shifting Boundaries, edited by Mirjana Morokvasic, Umut Erel, and Kyoko Shinozaki, 101-33. Schriftenreihe Der Internationalen Frauenuniversität »Technik Und Kultur« 10. VS Verlag für Sozialwissenschaften, 2003. http://link.springer.com/chapter/10.1007/978-3663-09529-3_6.

Nowak, Stefan. Społeczeństwo Polskie Czasu Kryzysu. Warsyawa: UW IS, 1984.

OECD. Trends in International Migration 1999: Continuous Reporting System on Migration. OECD Publishing, 1999.

Oswald, Lynda J. "Extended Voluntary Departure: Limiting the Attorney General's Discretion in Immigration Matters." Michigan Law Review 85, no. 1 (October 1, 1986): 152-90. doi:10.2307/1288886.

Programs, United States Dept of State Bureau for Refugee. Department of State Bureau for Refugee Programs Orientation Manual. The Dept., 1986.

Rachwald, Arthur R. In Search of Poland: The Superpowers' Response to Solidarity, 1980-1989. Hoover Press, 1990.

Roebuck, William V. Jr. "Move to Employment-Based Immigration in the Immigration Act of 1990: Towards a New Definition of Immigrant, The." North Carolina Journal of International Law and Commercial Regulation 16 (1991): 523.

Rolph, Elizabeth. Immigration Policies. Legacy from the 1980s and Issue for the 1990s. Santa Monica CA: RAND, 1992.

Rymarczyk, Janusz. Migracja Sity Roboczej Do Krajów EWG i Jej Konsekwencje Społeczno-gospodarcze. Poznań: Instytut Zachodni, 1986.

Sakson, Barbara. "Po Drugiej Stronie Oceanu. Nowi Emigranci z Polski w Metropolii Chicagowskiej." CMR Working Papers, no. 5/63 (2005). 
Shanks, Cheryl. Immigration and the Politics of American Sovereignty, 1890-1990. Ann Arbor: University of Michigan Press, 2002.

Solis, Dianna, and Constanza Montana. "Immigration-Amnesty Begins Smoothly But With Much Anxiety for Immigrants." Wall Street Journal, Eastern Edition. May 6, 1987.

Statistical Abstract of the United States. U.S. Government Printing Office, 1991.

Stepick, Alex, and Carol Dutton Stepick. "Diverse Contexts of Reception and Feelings of Belonging." Forum Qualitative Sozialforschung / Forum: Qualitative Social Research 10, no. 3 (September 29, 2009). http://www.qualitativeresearch.net/index.php/fqs/article/view/1366.

Stola, Dariusz. Kraj bez wyjscia?: migracje z Polski 1949-1989. Warszawa: Instytut Pamieci Narodowej, Komisja Scigania Zbrodni przeciwko Narodowi Polskiemu : Instytut Studiów Politycznych PAN, 2010.

"Three Decades of Mass Immigration: The Legacy of the 1965 Immigration Act." Center for Immigration Studies. Accessed December 4, 2013. http://cis.org/1965ImmigrationAct-MassImmigration.

Tichenor, Daniel J. Dividing Lines: The Politics of Immigration Control in America. Princeton University Press, 2009.

Times, MICHAEL T. KAUFMAN Special to The New York. "Poles, With Plenty of Passports, Line Up for Visas.” New York Times. July 22, 1985. http://search.proquest.com.www.libproxy.wvu.edu/hnpnewyorktimes/docview/1 11293401/abstract/1420EC7795C1BB8671C/99? accountid=2837.

Times, NATHANIEL C. NASH Special to The New York. "IMMIGRATION BILL APPROVED IN HOUSE: New Provisions Seek to Allow 775,000 Foreigners Yearly -- New Talent Is Goal." New York Times. October 4, 1990, sec. NATIONAL.

Times, ROBERT PeARSpecial to The New York. "Number of Poles and Hungarians Admitted as Refugees Will Be Cut: U.S. Planning to Curtail the Number of Poles and Hungarians Admitted as Refugees." New York Times. November 22, 1989.

United States. Immigration and Naturalization Service. Statistical Yearbook of the Immigration and Naturalization Service [microform]. Washington, D.C. : The Service : For sale by the Supt. of Docs., U.S. G.P.O., 1994. http://archive.org/details/statisticalyearb1994unit. . Statistical Yearbook of the Immigration and Naturalization Service [microform]. Washington, D.C. : The Service : For sale by the Supt. of Docs., U.S. G.P.O., 1997. http://archive.org/details/statisticalyearb1997unit.

Waters, Mary C., Reed Ueda, and Helen B. Marrow. The New Americans: A Guide to Immigration Since 1965. Harvard University Press, 2007.

Wojdon, Joanna. "W jedności siła”: Kongres Polonii Amerykańskiej w latach 19681988. Wydawnictwo Adam Marszałek, 2008.

Yarnold, Barbara M. "Politicized Judicial and Congressional Asylum Policymaking, 1980-1987.” The Justice System Journal 17, no. 2 (January 1, 1994): 207-20. doi:10.2307/27976856.

Zolberg, Aristide R., and Peter M. Benda. Global Migrants, Global Refugees: Problems and Solutions. Berghahn Books, 2001.

ZOLBERG, Aristide R., and Aristide R. Zolberg. A Nation by Design: Immigration Policy in the Fashioning of America. Harvard University Press, 2009. 